\title{
Climate change and wetland loss impacts on a western river's water quality
}

\author{
R. M. Records ${ }^{1}$, M. Arabi ${ }^{2}$, S. R. Fassnacht ${ }^{3}$, W. G. Duffy ${ }^{4}$, M. Ahmadi ${ }^{5}$, and K. C. Hegewisch ${ }^{6}$ \\ ${ }^{1}$ Integrated Water, Atmosphere, Ecosystems Education and Research Program, Department of Geosciences, \\ Colorado State University, 1482 Campus Delivery, Fort Collins, CO 80523-1482, USA \\ ${ }^{2}$ Department of Civil and Environmental Engineering, Colorado State University, 1372 Campus Delivery, \\ Fort Collins, CO 80523-1372, USA \\ ${ }^{3}$ Department of Ecosystem Science and Sustainability/Watershed Science, Colorado State University, 1476 Campus Delivery, \\ Fort Collins, CO 80523-1476, USA \\ ${ }^{4}$ US Geological Survey, California Cooperative Fish and Wildlife Research Unit, Humboldt State University, 1 Harpst Street, \\ Arcata, CA 95521, USA \\ ${ }^{5}$ Spatial Sciences Lab, 1500 Research Parkway, Suite 221B, Texas A\&M University, College Station, TX 77843, USA \\ ${ }^{6}$ Department of Geography, University of Idaho, Moscow, ID 83844-3120, USA
}

Correspondence to: R. M. Records (rosemary@lamar.colostate.edu)

Received: 14 March 2014 - Published in Hydrol. Earth Syst. Sci. Discuss.: 15 May 2014

Revised: 20 August 2014 - Accepted: 2 October 2014 - Published: 14 November 2014

\begin{abstract}
An understanding of potential stream water quality conditions under future climate is critical for the sustainability of ecosystems and the protection of human health. Changes in wetland water balance under projected climate could alter wetland extent or cause wetland loss (e.g., via increased evapotranspiration and lower growing season flows leading to reduced riparian wetland inundation) or altered land use patterns. This study assessed the potential climateinduced changes to in-stream sediment and nutrient loads in the snowmelt-dominated Sprague River, Oregon, western US. Additionally, potential water quality impacts of combined changes in wetland water balance and wetland area under future climatic conditions were evaluated. The study utilized the Soil and Water Assessment Tool (SWAT) forced with statistical downscaling of general circulation model (GCM) data from the Coupled Model Intercomparison Project 5 (CMIP5) using the Multivariate Adaptive Constructed Analogs (MACA) method. Our findings suggest that, in the Sprague River, (1) mid-21st century nutrient and sediment loads could increase significantly during the high-flow season under warmer, wetter climate projections or could change only nominally in a warmer and somewhat drier future; (2) although water quality conditions under some future climate scenarios and no wetland loss may be
\end{abstract}

similar to the past, the combined impact of climate change and wetland losses on nutrient loads could be large; (3) increases in stream total phosphorus (TP) concentration with wetland loss under future climate scenarios would be greatest at high-magnitude, low-probability flows; and (4) loss of riparian wetlands in both headwaters and lowlands could increase outlet TP loads to a similar degree, but this could be due to distinctly different mechanisms in different parts of the watershed.

\section{Introduction}

An understanding of potential stream water quality conditions under future climate is critical for the sustainability of ecosystems and the protection of human health (Mulholland and Sale, 2011). A large number of studies in the last decade have used hydrologic models to understand potential impacts of future climate on stream flow (e.g., Jha et al., 2004; Krysanova et al., 2005; Abbaspour et al., 2010; Diffenbaugh et al., 2013). However, less research has evaluated potential climate-induced changes in stream sediment and nutrient fluxes (Kundzewicz et al., 2009; Liu et al., 2010; Ahmadi et al., 2014). 
Few studies have assessed potential climate-induced changes to in-stream sediment loads in historically snowmelt-dominated rivers of the western US (an exception is Ficklin et al., 2010). To our knowledge, no hydrologic modeling studies have yet assessed future fluxes of nutrients in these rivers (see Oregon Climate Change Research Institute, 2010; Tillman and Siemann, 2011).

Most water quality climate impact studies in this region have focused on stream temperature (e.g., Isaak et al., 2010; Flint and Flint, 2011; Beechie et al., 2013) because of its important control on aquatic organisms' abundance, distribution, and population persistence (Isaak et al., 2010). Understanding potential changes to in-stream sediment and nutrients can help decision makers evaluate possible future stressors to aquatic ecosystems in addition to stream flow changes and warming (such as eutrophication) and to better manage for resilience to climate change.

Additionally, while wetlands are widely considered important in basin-scale stream water quality management (e.g., Mitsch and Gosselink, 2000a; Verhoeven et al., 2006), few studies have addressed the potential combined effects on water quality of changing climate and climate-induced changes in wetland extent. Of these few, most have assessed the benefits of current wetlands or wetland creation under future climate rather than risks of wetland loss (e.g., Whitehead et al., 2006; Woznicki et al., 2011; Van Liew et al., 2012; Ma et al., 2012).

However, flow in many American western streams has decreased during spring and early summer in the 20th century, and lower future summer flows combined with increased evapotranspiration could reduce water tables and riparian wetland inundation (Stewart et al., 2005; Perry et al., 2012). In turn, changes in wetland water balance under future climate could alter wetland extent and cause wetland type conversion or even loss (Burkett and Kusler, 2000; Candela et al., 2009; Meyer et al., 1999; Mulholland and Sale, 2011). In the western US, smaller streams in transient rain-snow basins could show more rapid and pronounced responses to climate change and extreme events than lowland rivers (Oregon Climate Change Research Institute, 2010; Waibel et al., 2013).

In this case, headwater riparian wetlands could be more affected by future climate than wetlands lower in the watershed or those distant from the river. It is important to evaluate the combined water quality impact of multiple wetlands on the basin scale, as their cumulative function in a watershed may be greater than the sum of the parts (Johnston et al., 1990). We do not yet have tools to predict watershed-scale climate change sensitivity of wetland extent or hydroecological functions related to water quality. It is possible that wetland areas could expand, particularly under wetter future climate. We believe that, in the absence of these predictive tools, we can gain a better understanding of system vulnerability by assessing stream water quality sensitivity to hypothetical scenarios of wetland loss under future climate.
Another knowledge gap is how future climate may affect stream water quality under diverse stream flow conditions. Many climate impact studies of stream water quality have assessed changes in long-term annual average flow. Assessment under a range of flows, however, provides clues to sources and processes of pollutant loading (US Environmental Protection Agency, 2007). A load duration curve, for example, shows the percent of time that a given pollutant load threshold has been equaled or exceeded, and it can be used to assess at what flow conditions water quality is impaired (US Environmental Protection Agency, 2007).

The primary goal of the study was to assess vulnerability of stream water quality to future climate and potential climate-induced wetland losses in the Sprague River watershed, southern Oregon, USA. Wetlands in this snowmeltdominated, semiarid watershed are believed to be an important non-point-source pollutant control measure for downstream water quality (Boyd et al., 2002; Mayer and Naman, 2011). However, the extent of wetlands and their role in basin water quality under a changing climate is uncertain. Specific objectives were to (1) characterize potential changes in stream flow, sediment, and nutrient loads under future climate and present-day wetland extent; (2) evaluate the sensitivity of nutrient loads to wetland loss under future climate and a variety of flow conditions; and (3) determine if the impact on nutrient loading from wetland loss was influenced by the order of the stream to which wetlands were adjacent and under what flows impacts were greatest.

The Sprague River watershed drains an area of about $4000 \mathrm{~km}^{2}$ in the Upper Klamath River basin. The Sprague River is supplied by three major tributaries: the South and North Forks, which join to form the Sprague River main stem near Beatty, Oregon, and the larger Sycan River, which reaches the main stem about $20 \mathrm{~km}$ downstream of this confluence (Fig. 1). During the combined calibration and validation periods (2001-2010), on average, the Sycan River contributed about $20 \%$ of flow at the Sprague River outlet, while the North and South Forks both contributed approximately $10-15 \%$. Between water years 2004 and 2006, the Sprague River tributaries were estimated to account for $80 \%$ of the suspended sediment near the Sprague River outlet, of which about $60 \%$ was from the South Fork of the Sprague River, about $30 \%$ from the North Fork of the Sprague River, and the remainder from the Sycan (Graham Matthews and Associates, 2007). During the 2000s, the Sycan River at site 4 (Fig. 1) contributed an estimated 4-9\% of the annual total nitrogen (TN) load near the Sprague River outlet (site 2, Fig. 1), and the middle North Fork of the Sprague River (site 5, Fig. 1) contributed 23-35\%; for TP (total phosphorus), these estimates are 6-18 and 13-23\%, respectively. The South Fork of the Sprague River's contributions to loads at the Sprague River outlet could not be estimated for this period because of a lack of nearby daily stream flow data to develop total monthly nutrient loads. 


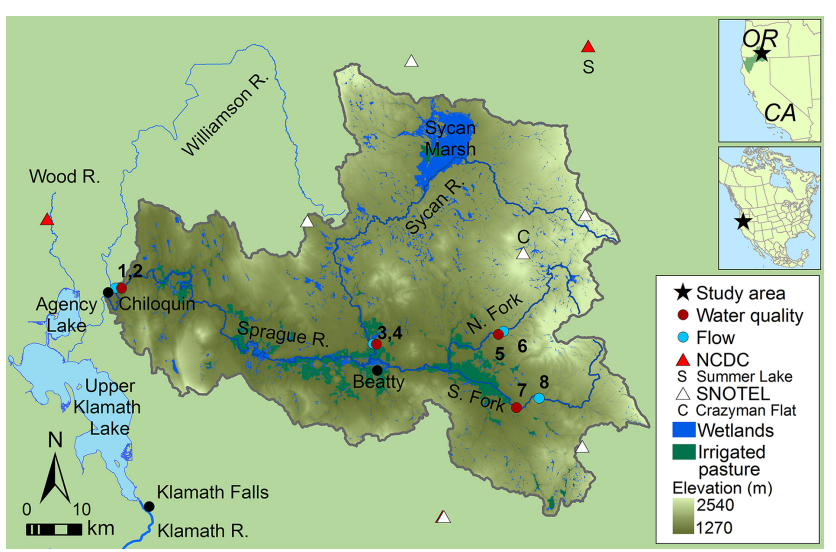

Figure 1. Sprague River watershed, Oregon, USA. Numbers of calibration and validation sites (circles) correspond to site information in Table 5. Data set sources are described in the text.

The Sprague River and the Williamson River, to which the Sprague drains, are two of the three largest tributaries to the large, shallow Upper Klamath Lake and contribute over half of the lake's inflow. Most of the remaining inflow to the lake is from the Wood River, which lies to the west of the Sprague and Williamson rivers (Fig. 1). Although the study area is a watershed in the western US, the general modeling framework (Fig. 2) is transferable to other basins where the relative sensitivity of water quality to future climate and land cover is of interest.

The Sprague River watershed lies in the rain shadow of the Cascade Mountains. Mean annual precipitation and temperature range from $340 \mathrm{~mm} \mathrm{yr}^{-1}$ and $10^{\circ} \mathrm{C}$ at the National Climatic Data Center (NCDC) station Summer Lake, approximately $15 \mathrm{~km}$ northeast of the watershed boundary, to $950 \mathrm{~mm} \mathrm{yr}^{-1}$ and $4{ }^{\circ} \mathrm{C}$ at the Snow Telemetry (SNOTEL) station Crazyman Flat in the headwaters of the Sycan River (1981-2010 averages obtained from http://www.wcc.nrcs. usda.gov/snotel/Oregon/oregon.html, last access 28 November 2011). Total annual precipitation is approximately $47 \%$ snow at lower elevations (SNOTEL station Taylor Butte, $1533 \mathrm{~m}$ a.s.l.) and $64 \%$ at higher elevations (SNOTEL station Summer Rim, 2158 m a.s.l.) (median percentage of precipitation as snow for water years 1981-2010). The majority of precipitation occurs between October and March. January is typically coldest, while July is typically warmest ( -3 and $15^{\circ} \mathrm{C}$ mean minimum and maximum monthly temperatures, respectively, at Summer Lake; -2 and $14^{\circ} \mathrm{C}$ at Crazyman Flat) (Fig. 1).

Elevation ranges from about 1270 to $2600 \mathrm{~m}$ a.s.l. (above sea level) (US Geological Survey, 2009). The Upper Klamath River basin geology generally consists of lava flows, volcanic rocks, or volcanic vents interbedded with sedimentary and volcaniclastic material (Gannett et al., 2007). The region's volcanic-derived soils are generally naturally rich in phosphorus $(\mathrm{P})$ and highly permeable in much of the watershed,

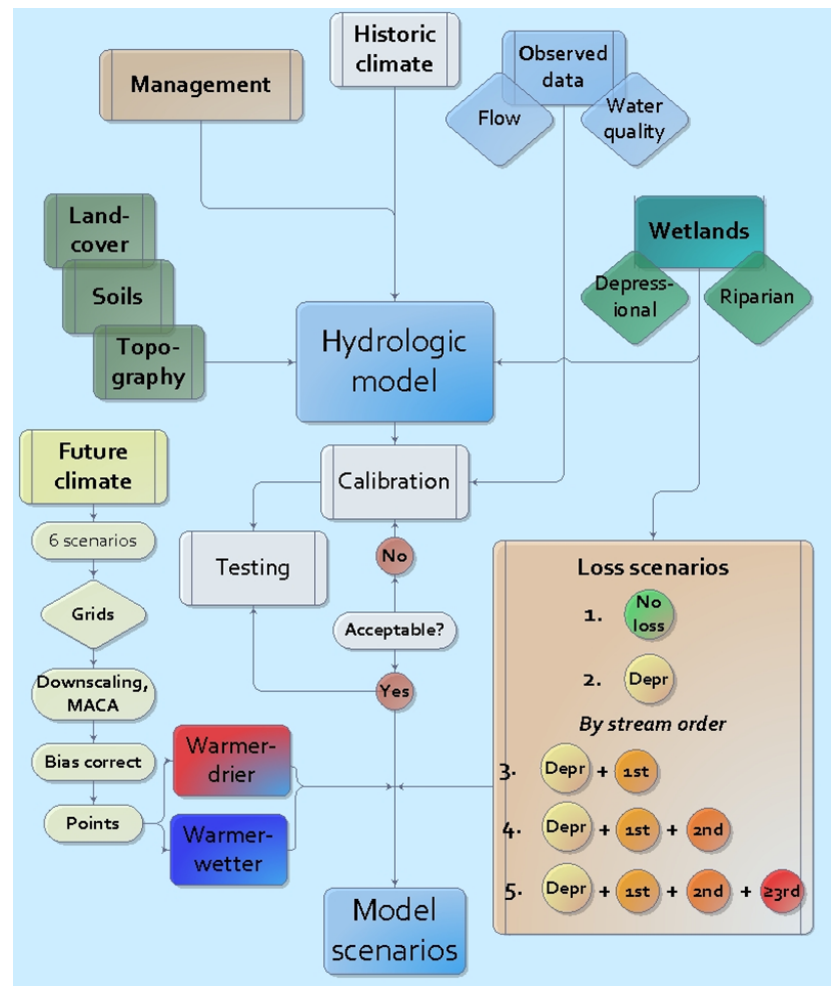

Figure 2. Overview of modeling framework used in this study. Framework components are described in further detail in the text. "Depr" indicates depressional wetlands, and "MACA" is a short form of "Multivariate Adaptive Constructed Analogs" (both terms are defined in the text).

particularly in young volcanic areas (Cahoon, 1985; Graham et al., 2005; Gannett et al., 2007). The majority of the watershed is coniferous forest dominated by Ponderosa and Lodgepole pine (Pinus ponderosa and Pinus contorta) (Rabe and Calonje, 2009). Other land cover is mostly rangeland, wetlands, and irrigated cattle pasture (Homer et al., 2007). Riparian and depressional wetlands comprise a total of about 5.3 and $0.4 \%$ of the Sprague River watershed, respectively. The distribution of riparian wetlands in the watershed (i.e., their prevalence along different stream orders) is summarized in Table 1.

Annual peak flows at the Sprague River outlet near Chiloquin, Oregon, generally occur between the months of February and June and are associated with snowmelt (Mayer and Naman, 2011; US Geological Survey, 2012). Groundwater discharge to streams is approximately 3 to $4 \mathrm{~m}^{3} \mathrm{~s}^{-1}$ in the North Fork of the Sprague River and in the lower Sprague River valley, but only about $1 \mathrm{~m}^{3} \mathrm{~s}^{-1}$ in reaches of the Sycan River and the South Fork of the Sprague River (Gannett et al., 2007).

TP loads to Upper Klamath Lake have increased in the last century to above background levels already high from regional volcanic geology (Boyd et al., 2002). About $45 \%$ of TP inflows to Upper Klamath Lake are from the Sprague 
Table 1. Percent of riparian wetland area within a $30 \mathrm{~m}$ buffer of streams in the Sprague River watershed by Strahler stream order (Strahler, 1952), percent of watershed area draining to each order, and percent of the total riparian wetland area within the entire watershed draining to each of the three stream classes. Percent of watershed area is calculated by first determining the stream order to which the majority of each hydrologic response unit's area drained, then calculating the total contribution of each stream order's drainage area to the watershed area. Percent of riparian area is the percent of the total riparian wetland area adjacent to streams of the three order classifications shown in the table. The geospatial data and analysis methods are described in the text.

\begin{tabular}{|c|c|c|c|}
\hline Stream order & $\begin{array}{c}\% \text { Buffer } \\
\text { area }\end{array}$ & $\begin{array}{c}\% \\
\text { Watershed } \\
\text { drainage } \\
\text { area }\end{array}$ & $\begin{array}{r}\% \text { Riparian } \\
\text { area }\end{array}$ \\
\hline 1 & 25 & 64 & 15 \\
\hline 2 & 17 & 10 & 7 \\
\hline$\geq 3$ and other & 58 & 26 & 78 \\
\hline
\end{tabular}

River alone (water years 1992-2010) (Walker et al., 2012). TP increases have been attributed to increased runoff and erosion in watersheds draining to the lake, and also to loss of over $90 \%$ of the Upper Klamath River basin's wetlands (Gearheart et al., 1995).

Elevated TP loads are associated with large blooms and die-offs of phytoplankton in Upper Klamath Lake, which cause extremes in $\mathrm{pH}$ and oxygen concentration that may be lethal to federally listed endangered fish species (Boyd et al., 2002). The Klamath River begins downstream of Upper Klamath Lake at the lake's dam-controlled outlet, from which the river flows some $400 \mathrm{~km}$ to the Pacific Ocean in California (VanderKooi et al., 2011) (Fig. 1). Upper Klamath Lake water quality can contribute to poor water quality downstream in the Klamath River by the export of high nutrient and organic-matter loads, which may also favor the growth of liver toxin producing cyanobacteria (Eldridge et al., 2012). The total maximum daily load (TMDL) target TP concentration for Upper Klamath Lake inflows was based on flow conditions in 1991-1998 (66 ppb) and represented a $40 \%$ decrease in annual TP loads to the lake. This concentration is nearly equivalent to the region's background TP concentration of $65 \mathrm{ppb}$ (Walker et al., 2012).

The primary land uses in the Sprague River watershed are the grazing of beef cattle in river valleys and timber harvest (Rabe and Calonje, 2009; US Department of Agriculture Natural Resources Conservation Service, 2009). The majority of pasture in the Sprague River valley is flood irrigated from surface water sources (US Department of Agriculture Natural Resources Conservation Service, 2009), so grazing rotations in the hydrologic model (described in detail below) were only assigned to irrigated lands designated for agricultural use by the Oregon Water Resources Department
(2008). Actual stocking rates in the watershed are not known and vary from year to year (D. Ferguson, Natural Resources Conservation Service Klamath Falls Service Center, Klamath Falls, Oregon office, personal communication, 2012). Therefore, we derived management parameter input to the hydrologic model from a plausible stocking rate of $4.9 \mathrm{head} \mathrm{ha}^{-1}$ (confirmed by NRCS staff), literature equations relating cattle mass to forage consumption and manure production, and regional literature (D. Ferguson, Natural Resources Conservation Service Klamath Falls Service Center, Klamath Falls, Oregon office, personal communication, 2012; Ciotti, 2005; American Society of Agricultural and Biological Engineers, 2006; US Department of Agriculture Natural Resources Conservation Service, 2009). Management details are shown in Table 2.

Much of the Upper Klamath River basin is in a transitional elevation zone where the form of precipitation (rain or snow) is sensitive to relatively slight changes in temperature (e.g., Mote, 2003; Sproles et al., 2013). The Upper Klamath Basin has shown warming, decreases in snow water equivalent, and earlier spring melt since the 1950s, similar to changes observed elsewhere in the American west (Mote, 2003; Mayer and Naman, 2011; Risley et al., 2012). While it appears quite possible that such trends will continue (Risley et al., 2012), the potential effects on the basin's water quality are not well understood.

\section{Methods}

\subsection{Hydrologic model}

The modeling framework consisted of a hydrologic model calibrated for historic observed climate forcings. The model was then run for a combination of future climate and wetland loss scenarios. Major components of the framework are summarized in Fig. 2. The Soil and Water Assessment Tool (SWAT) model was developed by the US Department of Agriculture (USDA) to assess land management impacts on hydrology and water quality over long time periods and has been used successfully in hundreds of water resources studies globally (Arnold et al., 1998; Gassman et al., 2007). SWAT is a continuous, distributed-parameter model that operates on a daily or more frequent time step. The model delineates a basin into subwatersheds, which are further divided into hydrologic response units (HRUs), unique combinations of soil type, land cover, and slope class (Neitsch et al., 2009). SWAT incorporates detailed moisture- and temperature-dependent terrestrial and in-stream cycling of $\mathrm{N}$ and $\mathrm{P}$. In-stream nutrient processes are based on the Enhanced Stream Water Quality Model (QUAL2E) and incorporate settling and hydrolysis of organic $\mathrm{N}$ and $\mathrm{P}$ to mineral forms; mineralization, benthic release, and algal uptake of ammonium and soluble inorganic phosphorus; and nitrification and algal uptake of nitrate (Brown and Barnwell, 1987; Neitsch et al., 2009). 
Table 2. Management parameters in the Soil and Water Assessment Tool (SWAT) model. Sources are described in the text. HRU stands for hydrologic response unit.

\begin{tabular}{|c|c|c|}
\hline Parameter & Description & Value \\
\hline Grazing rotation & Yearly start and end dates of grazing & 1 April to 30 September \\
\hline \multicolumn{3}{|c|}{ Forage } \\
\hline Type & Tall fescue (default SWAT pasture crop) & - \\
\hline Consumption & Dry biomass consumed per day & $29.5 \mathrm{~kg} \mathrm{ha}^{-1}$ \\
\hline Trampling & Dry biomass trampled per day & $29.5 \mathrm{~kg} \mathrm{ha}^{-1}$ \\
\hline Manure & Manure deposited per day & $7.7 \mathrm{~kg} \mathrm{ha}^{-1}$ \\
\hline \multicolumn{3}{|c|}{ Auto-irrigation } \\
\hline Schedule & Yearly start and end dates of irrigation & 1 June to 30 September \\
\hline Method & SWAT method to calculate irrigation depth & Plant demand \\
\hline Max. depth & Maximum depth of daily irrigation & $382 \mathrm{~mm} \mathrm{day}^{-1}$ \\
\hline Efficiency fraction & $\begin{array}{l}\text { Parameter accounting for losses } \\
\text { between irrigation source and applied location }\end{array}$ & 1 \\
\hline Runoff & $\begin{array}{l}\text { Fraction of irrigation applied to HRU } \\
\text { that leaves as surface runoff }\end{array}$ & 0.58 \\
\hline
\end{tabular}

Since the Sprague River tributaries and main stem each have unique hydrologic characteristics (Gannett et al., 2007), we set up four separate SWAT models for the Sycan, the North and South Forks of the Sprague River, and the Sprague River main stem using ArcSWAT (US Department of Agriculture Agricultural Research Service, 2011). Setup inputs were a $30 \mathrm{~m}$ National Elevation Dataset raster, a National Hydrography Dataset (NHD) high-resolution stream layer, a National Land Cover Dataset (NLCD) 2001, and the US General Soil Map (Homer et al., 2004; US Geological Survey, 2010a; US Department of Agriculture Agricultural Research Service, 2011). Each irrigated field designated for agricultural use by the Oregon Water Resources Department was modeled as a separate HRU of the NLCD 2001 land cover type dominant within that field (Oregon Water Resources Department, 2008). The sole point source in the watershed, the Chiloquin wastewater treatment plant (in the town of Chiloquin, shown in Fig. 1), was input to the SWAT model with the following average daily flow, organic $\mathrm{P}$, and soluble $\mathrm{P}$ effluent for the year: $378.5 \mathrm{~m}^{3} \mathrm{day}^{-1}$, $0.94 \mathrm{~kg} \mathrm{day}^{-1}$, and $0.57 \mathrm{~kg} \mathrm{day}^{-1}$, respectively, after Gu et al. (2011) and Boyd et al. (2002). We then forced the SWAT model with future climate projections and a suite of wetland loss scenarios (described below). The modeling framework was applied in an exploratory mode to assess the relative changes between simulated historic periods and future scenarios. A schematic of the hydrologic modeling framework and scenarios is shown in Fig. 2.

In the current SWAT model, wetlands are typically represented by two means. Riparian wetlands or buffers are represented as a filter strip, and a trapping efficiency for sediments and nutrients is calculated from strip width. Depressional wetland surface areas and volumes are aggregated to a single value per subwatershed, and a percentage of flow, sediment, and nutrients from each HRU is stored or removed in the aggregated wetland. This percentage is based on the user-assigned fraction of the subwatershed draining to wetlands. Sediment and nutrient removal occurs via settling under user-specified equilibrium concentrations. The underlying theory and calculations for both wetland types are detailed in Neitsch et al. (2005, 2009).

A number of previous studies have used the SWAT model to assess the role of wetlands in flow and water quality regulation, including Moriasi et al. (2011); Liu et al. (2007, 2008), Sahu and Gu (2009), and Cho et al. (2010a, b) for riparian wetlands or buffer strips, as well as Wang et al. (2008, 2010), Wu and Johnston (2008), Melles et al. (2010), and Almendinger et al. (2012) for depressional wetlands. These works have taken a diverse approach to wetland representation. For riparian wetlands, these approaches have included the use of the filter strip function in SWAT, sometimes in combination with an alteration to channel stability parameters or the SWAT's hillslope schemes, and the integration of SWAT with the Riparian Ecosystem Management Model or with custom modules. Studies of depressional wetlands have tended to use the existing SWAT module for depressional wetlands (within the water body or .pnd files). The hydrologic equivalent wetland (HEW) approach, which was applied to channel fens and bogs, includes wetland and channel parameters in the model calibration, such as wetland storage volume, tributary lengths, and channel roughness (Wang et al., 2008).

The SWAT model has also been used in a number of hydrologic modeling studies of climate change impacts. A detailed review is provided in Gassman et al. (2007). More recent research includes studies in the US - including the Midwest 
(Chaplot, 2007; Woznicki et al., 2011; Van Liew et al., 2012; Ahmadi et al., 2014), the San Joaquin River valley (Ficklin et al., 2010), and the Sierra Nevada mountains (Ficklin et al., 2013) of California; Canada (Shrestha et al., 2012) southern China (Li et al., 2011), northwest China (Zang et al., 2012), Korea (Park et al., 2011), and Iran (Abbaspour et al., 2010). In SWAT, users may specify atmospheric $\mathrm{CO}_{2}$ concentrations, but the model does not allow concentrations to vary with time as would be expected for a 30-year simulation period, so we held $\mathrm{CO}_{2}$ levels constant in simulations.

\subsection{Historic climate data}

Historic climate data input to the SWAT model were drawn from two daily data sets: the Global Historical Climatology Network (GHCN) and SNOTEL stations. The GHCN data were acquired from the National Climatic Data Center (NCDC, last access: 24 February 2012), and the SNOTEL data were acquired from the Natural Resources Conservation Service (NRCS, last access: 28 November 2011). The NCDC quality assures and quality controls GHCN data extensively prior to release (Durre et al., 2010), and we conducted no further quality control besides the removal of flagged data.

We performed quality control procedures on the SNOTEL data. We preprocessed SNOTEL water year cumulative precipitation values, which are particularly sensitive to daily errors, following the methods outlined by Serreze et al. (1999). Additionally, we filled daily data gaps by multiplying precipitation or adding temperature data from a surrogate station, using the calculated ratio (for precipitation) or difference (for temperature) between the two stations. The surrogate was the station with the highest coefficient of determination $\left(R^{2}\right)$ with the in-filled station and data available for the day in question. In the cases where observations were absent at all stations, or when $\left(R^{2}\right)$ values of the station with missing data and surrogate stations were less than 0.2 , data gaps were filled by the SWAT weather data generator developed by Sharpley and Williams (1990). Evapotranspiration was estimated using the Hargreaves method, which is calculated based solely on daily temperature inputs. The SWAT weather generator was used to generate the other two climatic variables required by the model from historical monthly statistics at nearby meteorological stations: daily solar radiation and relative humidity.

We divided each subwatershed into ten bands representing an equal change in elevation and applied lapse rates of precipitation and temperature derived from regressions for gridded long-term annual average climate normals and elevation data (US Geological Survey, 2009; PRISM Climate Group at Oregon State University, 2012). Lapse rates were calibrated within the $95 \%$ confidence interval around the regression slope and ranged from -3.6 to $-3.5^{\circ} \mathrm{C} \mathrm{km}^{-1}$ (temperature) and from 698 to $713 \mathrm{~mm} \mathrm{~km}^{-1}$ (precipitation) among the tributaries and main stem.

\subsection{Model calibration and validation}

The SWAT model was calibrated and tested using monthly flow, sediment, TN, and TP data at four stream flow gages and four locations sampled for water quality by the Klamath Tribes (Fig. 1) (Klamath Tribes, 2008). For all locations except for the South Fork of the Sprague River, sediment and nutrient grab samples were converted to monthly loads using the LOAD ESTimator (LOADEST) tool (Runkel et al., 2004), and calibration and validation were done for 2001-2006 and 2007-2010, respectively. For the South Fork of the Sprague River, the period of record for nearby continuous flow observations was too short for evaluating model performance, so we estimated daily nutrient loads from the grab samples and accompanying instantaneous flow measurements. Since long-term data were not available for the 2000s for this tributary, flow calibrations were done for even years from 1992 to 2003 and tested for odd years during the same time period.

We selected calibration parameters from a Morris sensitivity analysis for stream flow, sediment, TN, and TP and from a review of the SWAT literature (Morris, 1991). We calibrated each of the tributary models separately with dynamically dimensioned search (DDS) (Tolson and Shoemaker, 2007) algorithms, beginning calibration for flow and proceeding to sediment and nutrients. Manual calibration was used where necessary to fine-tune model performance. The daily outputs from each calibrated and tested tributary model were read as input data to a separate model for the Sprague River main stem using the inlet option in SWAT. The main stem model was then calibrated and tested without further alteration to calibrated tributary parameters. Final calibration parameters and values are shown in the supplementary information.

\subsection{Future climate projections}

Future temperature and precipitation data were drawn from a $4 \mathrm{~km}$ gridded statistical downscaling of general circulation model (GCM) outputs from 14 models participating in the Coupled Model Intercomparison Project 5 (CMIP5) using the Multivariate Adaptive Constructed Analogs (MACA) (Abatzoglou and Brown, 2012) method, which uses the surface meteorological data set of Abatzoglou (2013). These downscaled outputs were acquired from http://reacchpna.org/thredds/reacch_climate_ CMIP5_aggregated_catalog.html in February 2013. The SWAT weather generator was also used to generate daily solar radiation and relative humidity for the future period from historical monthly statistics, using the same methods as described in Sect. 2.2.

From 14 candidate GCMs, we selected three that were representative of extremes in temperature change and a range of precipitation change over the Sprague River watershed between the historic period (1950-2005) and the 2040s (Table 3). The 2040s is a useful planning horizon for the Pacific 
Table 3. General circulation models (GCMs) and Representative Concentration Pathways (RCPs) used in scenario analysis using the downscaled Coupled Model Intercomparison Project 5 (CMIP5) outputs from Multivariate Adaptive Constructed Analogs (MACA). Absolute change in average annual temperature $(\Delta T)$ and percent change in average annual total precipitation (\% change $\mathrm{P})$ are shown between the future period (2030-2059) and historic period (1950-2005). Values are averaged from daily $4 \mathrm{~km}$ gridded data over the entire Sprague River watershed.

\begin{tabular}{llrrrr}
\hline GCM abbreviation & Full GCM name & Country & RCP & $\Delta T\left({ }^{\circ} \mathrm{C}\right)$ & $\%$ Change P \\
\hline INMCM4 & Institute of Numerical Mathematics Climate Model 4 & Russia & 4.5 & 1 & -0.4 \\
& & & 8.5 & 1.4 & -3.5 \\
\hline \multirow{2}{*}{ MIROC5 } & Model for Interdisciplinary & Japan & 4.5 & 1.9 & 1.6 \\
& Research on Climate 5 & & 8.5 & 2.1 & 0 \\
\hline CanESM2 & Canadian Earth System Model 2 & Canada & 4.5 & 2.6 & 8.9 \\
& & & 8.5 & 3.1 & 11.1 \\
\hline
\end{tabular}

Northwest and is approximately the period when GCM climate projections begin to markedly diverge from each other (Salathé Jr. et al., 2007; Mote and Salathé, 2010) due to the future forcing experiments. The period 1950-2005 is recommended for comparisons between historic conditions and future hydroclimatic changes with the MACA data set, as the downscaling process matches precipitation and temperature statistics between observed and modeled historic data for this entire period. The climate of the 2040s is assessed with an average over the period 2030-2059 (Salathé Jr. et al., 2007; Mote and Salathé, 2010) and the climate of the historical period as an average over 1950-2005. Since each GCM simulates the historic period somewhat differently, all future changes we report are comparisons between the 2040s and the historical period simulated with forcings from the same GCM.

The three GCMs selected for this study were INMCM4, CanESM2, and MIROC5. As seen in Table 3, the INMCM4 model shows the least warming of all candidate projections and a moderate decrease in precipitation relative to the historic period, although it is not the driest of the 28 candidates. The CanESM2 model is both the warmest and wettest GCM among all candidates. The MIROC5 model represents moderate increases in both temperature and precipitation.

We used two Representative Concentration Pathways (RCPs 4.5 and 8.5) for a total of six distinct climate projections in this study. RCPs are climate scenarios with prescriptions for future radiative forcing under plausible greenhouse gas emission rates and mitigation efforts. RCP 8.5 is a continuation of our current trajectory of emissions (a businessas-usual scenario), which achieves a global radiative forcing by the year 2100 of $8.5 \mathrm{~W} \mathrm{~m}^{-2}$ more than preindustrial levels (Taylor et al., 2012). RCP 4.5 represents an optimistic future pathway of coordinated global policy and emissions resulting in only $4.5 \mathrm{~W} \mathrm{~m}^{-2}$ more than preindustrial levels.

Downscaled projections at $4 \mathrm{~km}$ grid cell resolution maintain the statistics from the training data utilized by MACA. However, statistical differences between raster data and station data can be quite pronounced, necessitating that the projections be adjusted for station location. The daily downscaled data were adjusted by applying the same bias correction procedure utilized in MACA (the nonparametric equidistant cumulative distribution function matching method, or EDCDFm) quantile-mapping method of Li et al., 2010), with station observations as the training data to ensure that the historical period of the data had the same statistics as the station data. This process was performed at the eight SNOTEL and NCDC stations used for SWAT model forcing (shown in Fig. 1).

Stream flow and water quality projections at the Sprague River outlet were assessed for the 2040s using the baseline period 1954-2005 (where the years 1950-1953 were used as a warm-up period for the SWAT model). First, the effects of climate change alone were assessed using all six projections for the 2040s. Second, the combined effect of changing climate and wetlands on water quality were assessed with wetland loss scenarios under the two climate projections representing the greatest extremes in warming and precipitation change out of our six projections (Table 3). The projections chosen were RCP 8.5 CanESM2 and RCP 8.5 INMCM4, subsequently referred to as the "warmer-wetter" and "warmer-drier" climate scenarios, respectively.

\subsection{Wetland loss scenarios}

\subsubsection{Baseline wetlands}

Regional wetland and water body spatial databases were used to identify the current area and type of wetlands and lakes within the Sprague River basin (Oregon Natural Heritage Information Center and the Wetlands Conservancy, 2009; US Geological Survey, 2010a, b; US Department of Agriculture Natural Resources Conservation Service, 2011; US Fish and Wildlife Service, 2011). Mapped wetlands adjacent to streams and rivers, which comprise the majority of wetland area in the Sprague watershed, were classified as riparian. Following the methods of Cho et al. (2010a), we created a $30 \mathrm{~m}$ buffer to all streams in a high-resolution network 
Table 4. Depressional wetland model parameters, equations, and sources. "Name"is the parameter name in the SWAT (Soil and Water Assessment Tool) pond file. "Wetlands database" refers to Oregon Natural Heritage Information Center and the Wetlands Conservancy (2009), US Geological Survey (2010a), US Department of Agriculture Natural Resources Conservation Service (2011), and US Fish and Wildlife Service (2011).

\begin{tabular}{|c|c|c|c|c|}
\hline Name & Description & Units & Sources & Value or equation \\
\hline WET_FR & $\begin{array}{l}\text { Fraction of } \\
\text { subwatershed draining } \\
\text { to wetlands }\end{array}$ & - & Wetlands database & - \\
\hline WET_MXSA & Max. surface area & ha & Wetlands database & - \\
\hline WET_NSA & Normal surface area & ha & $\begin{array}{l}\text { Liu et al. (2008) } \\
\text { Wu and Johnston (2008) }\end{array}$ & WET_MXSA $\cdot 0.45$ \\
\hline WET_NVOL & Normal volume & $10^{4} \mathrm{~m}^{3}$ & $\begin{array}{l}\text { Liu et al. (2008) } \\
\text { Wu and Johnston (2008) }\end{array}$ & $\begin{array}{l}\text { Average of: } \\
\text { WET_NSA } \cdot 0.1 \\
\text { WET_MXVOL } \cdot 0.4\end{array}$ \\
\hline WET_MXVOL & Max. volume & $10^{4} \mathrm{~m}^{3}$ & $\begin{array}{l}\text { Liu et al. (2008) } \\
\text { Wu and Johnston (2008) }\end{array}$ & WET_MXSA $\cdot 0.35$ \\
\hline IFLOD1 & $\begin{array}{l}\text { Beginning month of } \\
\text { non-flood season }\end{array}$ & - & $\begin{array}{l}\text { Identified } \\
\text { from } \\
2001-2010 \\
\text { hydrographs for } \\
\text { each } \\
\text { tributary }\end{array}$ & $\begin{array}{l}\text { Sycan, N. and S. } \\
\text { Forks: Aug; } \\
\text { Sprague main stem: Jul }\end{array}$ \\
\hline IFLOD2 & $\begin{array}{l}\text { Ending month of } \\
\text { non-flood season }\end{array}$ & - & & $\begin{array}{l}\text { Sycan and N. Fork: Feb; } \\
\text { N. Fork: Feb; } \\
\text { N. Fork: Feb; } \\
\text { S. Fork: Oct }\end{array}$ \\
\hline
\end{tabular}

(NHD - High flow line) (US Geological Survey, 2010a) of the Sprague River watershed and then calculated the fraction of the buffer comprised of riparian wetlands within each subwatershed. We then multiplied this fraction by 30 to estimate riparian wetland width in meters for each subwatershed and set the filter strip width ("FILTERW" parameter in the corresponding SWAT management file) to this value.

We manually classified streams in the high-resolution network by Strahler stream order (Strahler, 1952). We then assigned each HRU the stream order to which the majority of the HRU area drained, using drainage areas calculated with ArcGIS Desktop Spatial Analyst Flow Direction and Watershed tools, which delineated a contributing drainage area for each stream segment within the network and identified the stream order associated with each drainage area. We then intersected an HRU map with drainage area delineations to determine the stream order to which the majority of each HRU drained (ArcGIS Desktop: Release 9.3., Environmental Systems Research Institute, Redlands, California, USA).

Where multithread channels occurred, side channels were assigned the stream order of the main channel. All multithread channels occurred along streams of third order or greater, which we grouped in our analysis below. Therefore, the classification of these types of channels should not impact results. Several streams could not be classified because they were disappearing streams or canal networks. Disappearing streams in the Upper Klamath can occur where stream flow rapidly infiltrates into the permeable volcanic geology (Gannett et al., 2007), and they are most prevalent in western parts of the Sprague River watershed. Canal and ditch networks are concentrated in the lower South Fork of the Sprague River and its confluence with the Sprague River main stem, but information on inflows and outflows from these networks was not available. Wetlands along either of these types of waterways were classified as "other" and were removed only in the scenario of loss of all wetlands (below).

Wetlands that were not adjacent to rivers and streams were modeled as depressional using the SWAT pond input files (described above). We derived pond and wetland geometries from the geospatial data described above and from surface-area-to-volume equations in literature, and we estimated drainage area using the ArcGIS Flow Direction and Watershed tools described above. Wetland geometry equations and the literature sources for the calculations are shown in Table 4.

Sycan Marsh is a large (approximately $1000 \mathrm{ha}$ ) surfacewater-dominated wetland in the headwaters of the Sycan River (Fig. 1). Since it both buffers the riparian corridor and 
attenuates floodwater in the Sycan River headwaters, it was represented as both a riparian and a depressional wetland within the model.

\subsubsection{Wetland scenarios}

We employed scenarios of wetland loss beginning in headwaters and proceeding downstream to assess the potential cumulative impacts on water quality under future climate in this basin. The scenarios used represent hypothetical responses of the Sprague River watershed to climate-induced changes in water balance (e.g., lowered water tables from increased evapotranspiration and reduced growing season stream flows), with the consideration that wetlands in mountainous regions and wetlands or streams with small contributing areas are likely to be more responsive to changes in climate (Winter, 2000; Waibel et al., 2013). However, anthropogenic changes to wetlands (e.g., drainage and cultivation, or restoration) could also occur in the future, either independently of climate change or as an adaptation measure to changing climate. Future land cover is likely to reflect complex anthropogenic and hydroclimatic feedbacks.

We assessed the four wetland loss scenarios under two of our six climate projections - "warmer-wetter" and "warmer-drier" - to determine potential water quality effects under diverse future climate conditions: (1) depressional wetlands only - all depressional wetland volumes, surface areas, and drainage areas were set equal to 0 , and no riparian wetlands were lost; (2) depressional and first-order wetlands - as for scenario 1, with all filter strip widths ("FILTERW" parameter in the SWAT management file) set equal to 0 in HRUs draining to first-order streams; (3) depressional, first and second-order wetlands - as for scenario 2 but for all HRUs draining to first and second-order streams; and (4) all wetlands - all depressional and riparian wetlands removed from the model, including wetlands along thirdorder and greater (hereafter "lowland") streams and wetlands along "other" waterways (disappearing streams and canals, described above). For comparability, we employed the same wetland loss scenarios for both climate projections. While patterns of wetland change could be distinctly different under the "warmer-wetter" or "warmer-drier" projection, modeling of such changes was beyond the scope of this study.

\subsection{Statistical analyses}

To compare the hydrologic model simulations to observations, we used thresholds for monthly model performance recommended by Moriasi et al. (2007). Performance during the calibration period was considered acceptable at a monthly time step if the Nash-Sutcliffe coefficient (NS) was greater than or equal to 0.5 and the percent bias ( $\left.P_{\text {BIAS }}\right)$ was within recommended thresholds: $\leq \pm 25 \%$ for stream flow, $\leq \pm 55 \%$ for sediment, and $\leq \pm 70 \%$ for TN and TP. The variation in acceptable $P_{\mathrm{BIAS}}$ for different constituents is due to higher measurement uncertainty in observed sediment and nutrient data (Moriasi et al., 2007). The NS statistic ranges from $-\infty$ to 1.0 , with 1.0 indicating a perfect fit between observed and simulated data plotted on a $1: 1$ line. Values $\leq 0$ indicate that the mean of observations is a better predictor than the model. The $P_{\mathrm{BIAS}}$ statistic measures the average tendency of simulated values to be lesser or greater than the corresponding observations. Positive (negative) values indicate a model bias to underestimation (overestimation) (Moriasi et al., 2007).

Generally, model performance criteria are less strict for calibration on shorter time steps (e.g., daily vs. monthly) and validation periods (Engel et al., 2007; Moriasi et al., 2007). Model monthly performance during validation and model daily performance during both calibration and validation were considered acceptable if the NS was greater than or equal to 0.2 and if $P_{\text {BIAS }}$ was within the ranges described above for monthly calibration. This model performance is within the range of similar studies which used SWAT (Santhi et al., 2001; Bracmort et al., 2006; Jha et al., 2007; Bosch, 2008; Sahu and Gu, 2009; Cho et al., 2010a; Lam et al., 2011).

To compare hydrologic model simulations of flow and loads between time periods and wetland loss scenarios, we employed several nonparametric tests (described below), as water quality data are often not normally distributed (Helsel and Hirsch, 2002). We used the $\alpha$ significance level of 0.1 for all such tests, as we considered it more important to identify differences in the data than to minimize the probability of rejecting a null hypothesis when it was true (type I error).

We used a two-tailed Mann-Whitney-Wilcoxon test to assess whether annual and monthly average flow and total load of sediment, TN, and TP for the 2040s under a given climate projection and wetland scenario differed from a future baseline with no wetland losses ( $n=30$ and $n=52$, respectively, annually and for each calendar month).

Additionally, we used load duration curves (described above) to assess the combined impacts of climate change and wetland loss on TP under a range of flow magnitudes. The load duration curve threshold was calculated as the total load for a given day's simulated flow under the TMDL target TP concentration of $66 \mathrm{ppb}$, which is essentially the regional background concentration (Walker et al., 2012).

For each of the two climate projections (warmer-wetter and warmer-drier), we classified daily simulated historic and future loads under wetland loss scenarios into typical load duration curve zones, with the total number of simulations from the historic period equaling 18993 (1954-2005 daily data) and the total in the future period equaling 10957 (2030-2059 daily data). These standard zones are based on the exceedance probability of a load's corresponding daily average stream flow: high (0-10\%), moist (10-40\%), mid-range (40-60\%), dry (60-90\%), and low (90-100\%) (Fig. 5) (US Environmental Protection Agency, 2007). Within each load duration curve zone, or flow class, we used 
the Kruskal-Wallis test to determine whether the six groups of daily loads (baseline wetlands under historic climate, baseline wetlands under future climate, and the four wetland scenarios under future climate) had the same medians.

\section{Results and discussion}

\subsection{Model performance}

Model monthly performance was generally acceptable for stream flow, sediment, and TP at the four calibration and validation locations (Table 5), although monthly stream flow $P_{\text {BIAS }}$ at the North Fork of the Sprague River was slightly outside the acceptable range ( $31 \%$ overestimation). The simulated 10-year monthly average for March and May from 2001-2010 tended to be somewhat higher and lower, respectively, than observations at the US Geological Survey gauge near the outlet of the Sprague River (station 1 in Fig. 1). However, $P_{\text {BIAS }}$ was within $\pm 6 \%$ and NS was greater than 0.7 for both the calibration and validation periods. $P_{\text {BIAS }}$ between mean daily observed and simulated flow at the Sprague River outlet (site 1, Fig. 1) for the calibration period 2001-2006 (validation period, 2007-2010) was 6\% $(22 \%)$ for the high-flow class, $-9 \%(-14 \%)$ for the moist class, $24 \%(-13 \%)$ for mid-range, $22 \%(-8 \%)$ for dry conditions, and $-56 \%(-73 \%)$ for low-flow conditions.

TN loads tended to be underestimated at the South Fork of the Sprague River and at the Sycan River (Table 5). Higher TN observations than simulated could be due to return flow from flood-irrigated pastures near waterways, from cattle entering streams (e.g., Ciotti, 2005), and periodic exports of nutrients from Sycan Marsh (Wong and Bienz, 2011, as cited in CH2MHILL, 2012). The calibrated hydrologic model driven with baseline GCM data simulated observed annual runoff fairly well. The 52-year average annual runoff for GCMdriven simulations was $2 \%$ (MIROC5) to $5 \%$ (INMCM4) greater than the observed average of $143 \mathrm{~mm} \mathrm{yr}^{-1}$ at the US Geological Survey gauge at Sprague River near Chiloquin, Oregon.

\subsection{Future hydrology and water quality under baseline wetlands}

Model performance statistics were within the range of similar studies using SWAT (Santhi et al., 2001; Bracmort et al., 2006; Jha et al., 2007; Bosch, 2008; Sahu and Gu, 2009; Cho et al., 2010a; Lam et al., 2011), and although $P_{\text {BIAS }}$ for nutrients was relatively high for some tributaries, it was generally within recommended thresholds accounting for the large measurement uncertainty in $\mathrm{N}$ and $\mathrm{P}$ observations (Moriasi et al., 2007). We consider the model performance adequate for an exploratory application of the modeling framework to assess relative changes between scenarios, particularly considering that the multisite, multiobjective calibration will necessarily result in some performance tradeoffs, and
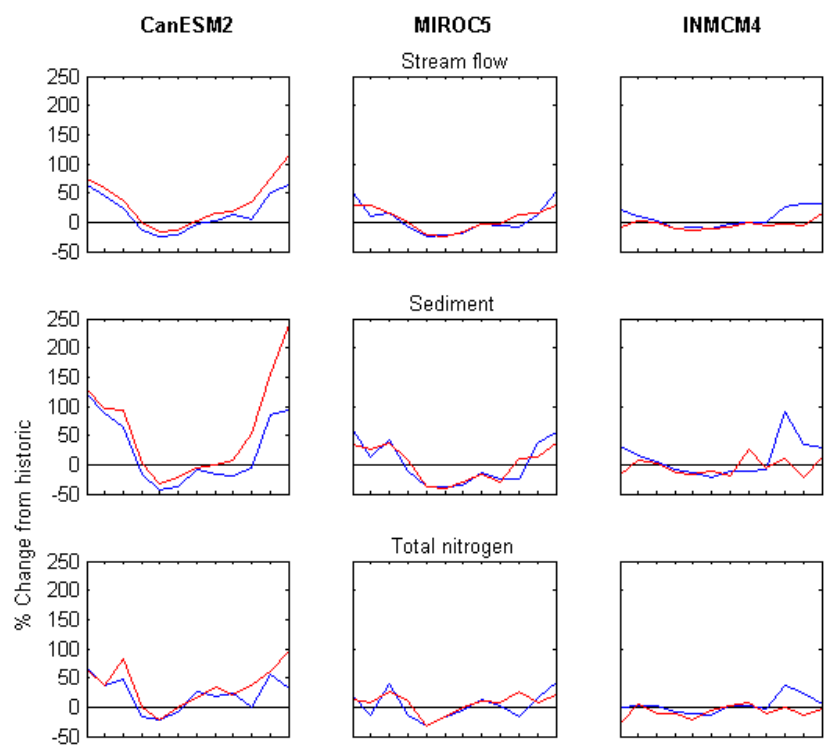

Total nitrogen
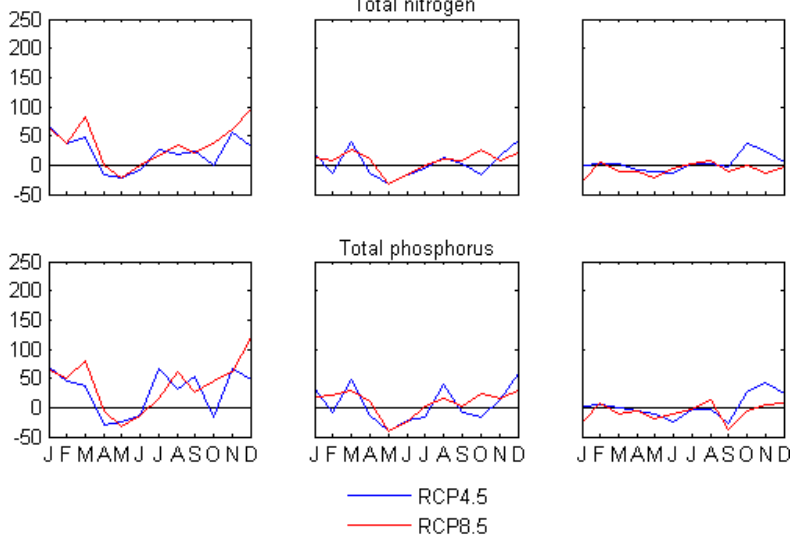

Figure 3. Percent change in simulated average monthly stream flow, sediment, and nutrients at the Sprague River outlet under three general circulation models (GCMs) and two Representative Concentration Pathways (RCPs). Changes are between long-term monthly averages for 1954-2005 and 2030-2050 hydrologic model simulations forced with GCM climate data and baseline wetland extent.

that scenario results are reported only for the Sprague River main stem, where model performance was generally satisfactory to very good (Moriasi et al., 2007).

Percent change in stream flow, water quality, and nutrients for the six climate projections are shown in Fig. 3. Average annual runoff increased by as much as 6-31\% between the baseline period (1954-2005) and the 2040s in five of the six simulations. However, baseline and future annual runoff were significantly different in only two simulations (RCP 4.5 CanESM2, $p<0.05$, and RCP 8.5 CanESM2, $p<0.001$ ). Only the "warmer-drier" RCP 8.5 INMCM4 projection simulated a decrease in runoff (4\%), which was not significantly different from the baseline $(p>0.1)$.

Average monthly stream flow increased from October through March and in most simulations was significantly different from the baseline for all or some of these months $(p<0.1)$. Increases in average monthly flow for a given simulation during this period were as high as 16-115\%, within the range of 2050s stream flow changes in the Western Cascades given in the literature (Waibel et al., 2013). 
Nearly all simulations showed modest decreases in average monthly stream flow from April through summer. These changes were significantly different from the baseline in only one or two simulations out of the six. Decreases in April flow could be attributed to more snowmelt occurring earlier in the season and a lower snowpack, which has been observed and projected elsewhere in the western US (Mote, 2003; Hamlet et al., 2007; Jefferson, 2011; Risley et al., 2012; Diffenbaugh et al., 2013; Sproles et al., 2013).

In this study, solar radiation and relative humidity were derived from historical monthly statistics at nearby meteorological stations for both the historic period and future climate simulations. This could have resulted in some overestimation of relative humidity for the future period, as relative humidity in the western US is projected to decrease by approximately $0.1-0.6 \%$ per decade, with higher rates in the interior US and in spring and summer (Pierce et al., 2013). Future changes in cloud cover could also result in different solar radiation values from the historic values used in the model.

We believe that the influence of solar radiation and relative humidity inputs in our model setup is likely relatively small. When the Hargreaves method for calculating potential evapotranspiration is used, as in this study, the only aspect of the SWAT model that may be affected by relative humidity is the vapor pressure deficit, which can influence plant growth (Neitsch et al., 2009). Vapor pressure deficit in SWAT is also governed by temperature inputs (drawn from downscaled GCM products for the future period in this study), and the rate of change in relative humidity from historic values is likely to be comparatively modest (Pierce et al., 2013). Similarly, when the Hargreaves method is used to calculate potential evapotranspiration, solar radiation inputs to the SWAT model affect only the total energy available to calculate potential plant and algal growth. Given inherent uncertainty in the model framework, any influence of relative humidity and solar radiation inputs on model results is likely modest.

Greatest percent increases in monthly average sediment and nutrient loads occurred in the high-flow season (approximately October through March) and ranged from 26 to $242 \%$ (sediment), 13 to $121 \%$ (TN), and 8 to $97 \%$ (TP). The greatest percent decreases were from April through September for sediment (4-44\%) and April through June for TN (4-41\%) and TP (7-33\%). These are within the range of potential climate-induced changes reported for other watersheds, although such changes can be expected to vary widely by region, time period modeled, and choice of climate forcing data (Bouraoui et al., 2002; Ficklin et al., 2010; Woznicki et al., 2011; Van Liew et al., 2012).

Other studies (e.g., Jeppesen et al., 2009; Shrestha et al., 2012) have reported the dilution of nutrients in future climate simulations in historically snowmelt-dominated watersheds. In our case, average annual nutrient concentrations changed little between the historic and future periods under climate change alone for any of the six projections, and percent changes in nutrient loads were generally proportional to changes in flow. One exception was the much warmer and wetter RCP 8.5 CanESM2 simulation, where average annual sediment concentration increased by about $10 \%$ and percent increases in sediment load were much larger than increases in runoff (Fig. 3). This may be explained by the typically logarithmic increase of sediment loads with stream flow (Novotny, 2003) and the decreased soil cover from snow reported by Sproles et al. (2013). Increased rainfall impact and winter runoff due to precipitation phase change could also contribute to increased erosion under future climate (Ficklin et al., 2013). However, Ficklin et al. (2013) reported a significantly negative correlation between simulated future snowmelt and sediment concentration in the American Sierra Nevada in the 21st century, which they associated with increased soil erosion from the loss of snowpack cover.

\subsection{Future water quality under wetland losses}

The majority of wetlands in the Sprague River watershed are riparian. In our modeling setup only pollutants intercepted from upslope runoff and subsurface nitrate are removed in the riparian zone, and riparian areas do not affect the model's hydrology (Neitsch et al., 2005). Overbank flooding to riparian areas is not yet included in standard versions of SWAT (Mitsch and Gosselink, 2000b; Neitsch et al., 2009), although it has been simulated in various extensions to the SWAT model such as the HEW (Wang et al., 2008) and other modules (Liu et al., 2008). While overbank flooding and exchange of sediment and nutrients with riparian areas could be an important aspect of Sprague River water quality, these processes have yet to be well characterized and so were not included in this study's modeling framework. This should be taken into consideration when assessing model results.

Wetland loss had almost no impact on flow at the Sprague River outlet, resulting in increases in average annual runoff of $<1 \%$ compared to future flows with no wetland losses. This is to be expected with the present hydrologic model setup. Even total loss of wetlands only slightly increased annual sediment loads above the future fluxes simulated under baseline land use (by 2 and $7 \%$, respectively, under the warmer-drier and warmer-wetter climate forcings). This could indicate the importance of bank and channel erosion as a sediment source in the Sprague River watershed, relative to upslope erosion (Graham Matthews and Associates, 2007).

Total wetland loss increased average annual TN by $23 \%$ and TP by $58 \%$ above future loads with no wetland loss under the "warmer-drier" scenario, compared to 31 and $97 \%$, respectively, under the "warmer-wetter" scenario (Fig. 4). Since flows were nearly identical among the wetland scenarios, this is due almost entirely to increasing nutrient concentrations. In the warmer-drier simulation, annual TP and TN loads without wetland loss were not significantly different from the past. However, any losses in addition to depressional and first-order wetlands yielded future TP loads significantly different from historic climate $(p<0.1)$. This 


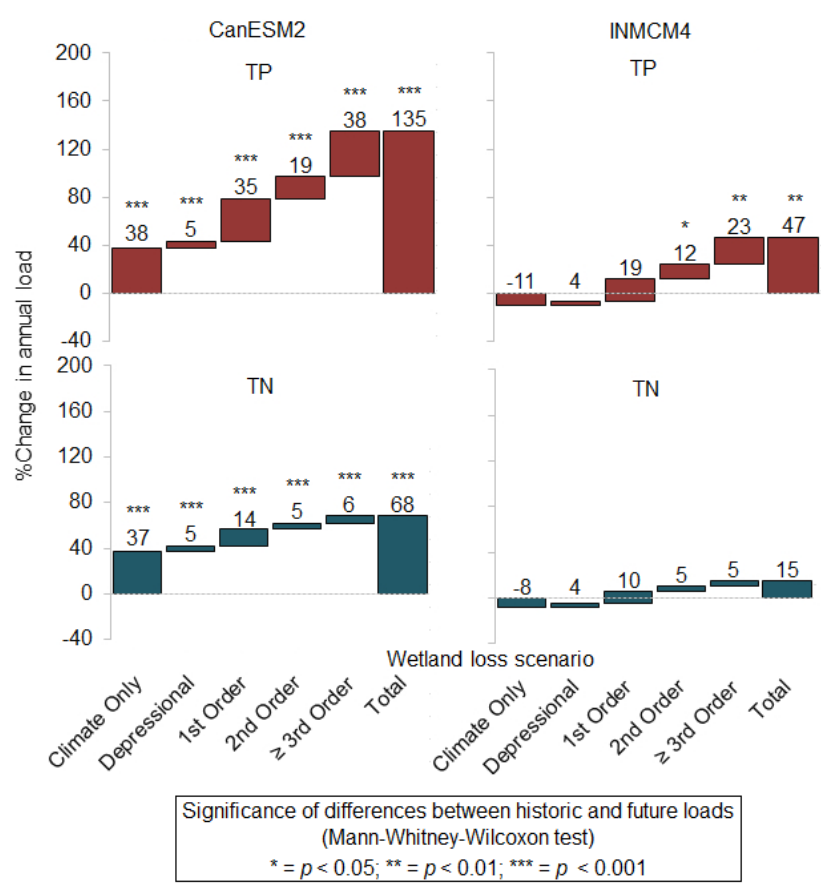

Figure 4. Percent change in simulated average annual loads of total phosphorus (TP) and total nitrogen (TN) at the Sprague River outlet under wetland loss scenarios for the period 2030-2059 for two general circulation models under Representative Concentration Pathway (RCP) 8.5, compared to historic climate (baseline wetland extent, 1954-2005).

suggests that the combined impact of climate change and wetland losses on nutrient loads could be large, even when future water quality conditions under no wetland loss are similar to the past.

Lowland and "other" riparian wetlands drain less HRU area than first-order streams (26\% versus $64 \%$ of the watershed) but comprise more of the watershed's riparian buffer area (58\% versus $25 \%$, Table 1$)$. The near-equal increases in TP loads caused by riparian wetland loss in first-order and lowland/ "other" streams could be due to the greater percentage of riparian area along lowland streams, combined with higher TP loading per unit area in the valley bottoms. In a field study in the Chesapeake Bay watershed, US, Pionke et al. (2000) found that the majority of erosion and sediment-associated, bioavailable $\mathrm{P}$ was generated near the watershed outlet where surface runoff intersected agricultural land. In the Sprague River watershed, most agriculture is flood-irrigated pasture land concentrated in valleys in the lower South Fork of the Sprague River and Sprague River main stem (US Department of Agriculture Natural Resources Conservation Service, 2009). These pastures may have high nutrient concentrations in runoff (e.g., Ciotti et al., 2010).
Riparian buffers in other headwater streams appear to be important in reducing nutrient loads. Lowrance et al. (1997) conceptualized a decreasing impact of riparian forest buffers on water quality with increasing stream order in the Chesapeake Bay watershed, USA, as the proportion of nutrients from upstream sources that could not be filtered by adjacent riparian areas increased. Tomer et al. (2009) applied a GIS-based analysis to soil survey data, and topographic and stream flow information from two Iowa watersheds, USA, to assess how effectively a riparian buffer could trap sediment from adjacent areas and where buffers were most likely to intercept runoff to streams. They found that riparian buffers along first-order streams had the most potential to improve water quality in runoff. Using the SWAT model, Cho et al. (2010a) found that the restoration of a fragmented riparian corridor on first- or second-order streams could reduce TP loads at the outlet of a Georgia, USA, watershed by about $15-20 \%$ each, as compared to $<5 \%$ reductions from restoration along third- or higher-order streams. TN reductions from first- and second-order restoration were more modest $(5-8 \%)$ and $<5 \%$ for higher-order streams, where agricultural areas are closer to waterways than in lowland streams. In contrast, Johnston et al. (1990) noted from their literature review that upland riparian areas may not efficiently trap P, the majority of which is sorbed to sediment, but that floodplain wetlands may retain this nutrient fraction well. Our findings suggest that loss of riparian wetlands in both headwaters and lowlands could have a similar effect on outlet TP loads, but this could be due to distinct mechanisms in different parts of the watershed.

Wetland loss had the most impact on TP loads under highmagnitude, low-probability flows (Fig. 5). For each flow class within the load duration curve (high, moist, mid-range, dry, and low, as defined in the section "Statistical analyses"), loads were significantly different from each other under the six wetland scenarios (baseline wetlands under historic climate, baseline wetlands under future climate, and the four wetland loss scenarios under future climate). As noted above, load differences are due almost entirely to increases in TP concentration from wetland loss.

There is only one small point source of $\mathrm{TP}$ in the watershed (Chiloquin wastewater treatment plant, described above), so low flow loads are dominated by background TP in baseflow. Even total loss of wetlands has little relative or absolute impact on these low flow loads because the riparian zone reduces TP only in surface runoff (Neitsch et al., 2005). At higher flows, a greater proportion of the total flow is surface runoff, and the bulk of $\mathrm{P}$ transport occurs (Withers and Jarvie, 2008), so the loss of riparian wetlands has a much greater impact during floods. This is particularly relevant because more frequent flooding may occur under climate change (Solheim et al., 2010), a general prediction that is apparent in our "warmer-wetter" simulation but not in our "warmer-drier" simulation (Fig. 5). Johnston et al. (1990) observed that wetlands in multiple Midwestern 


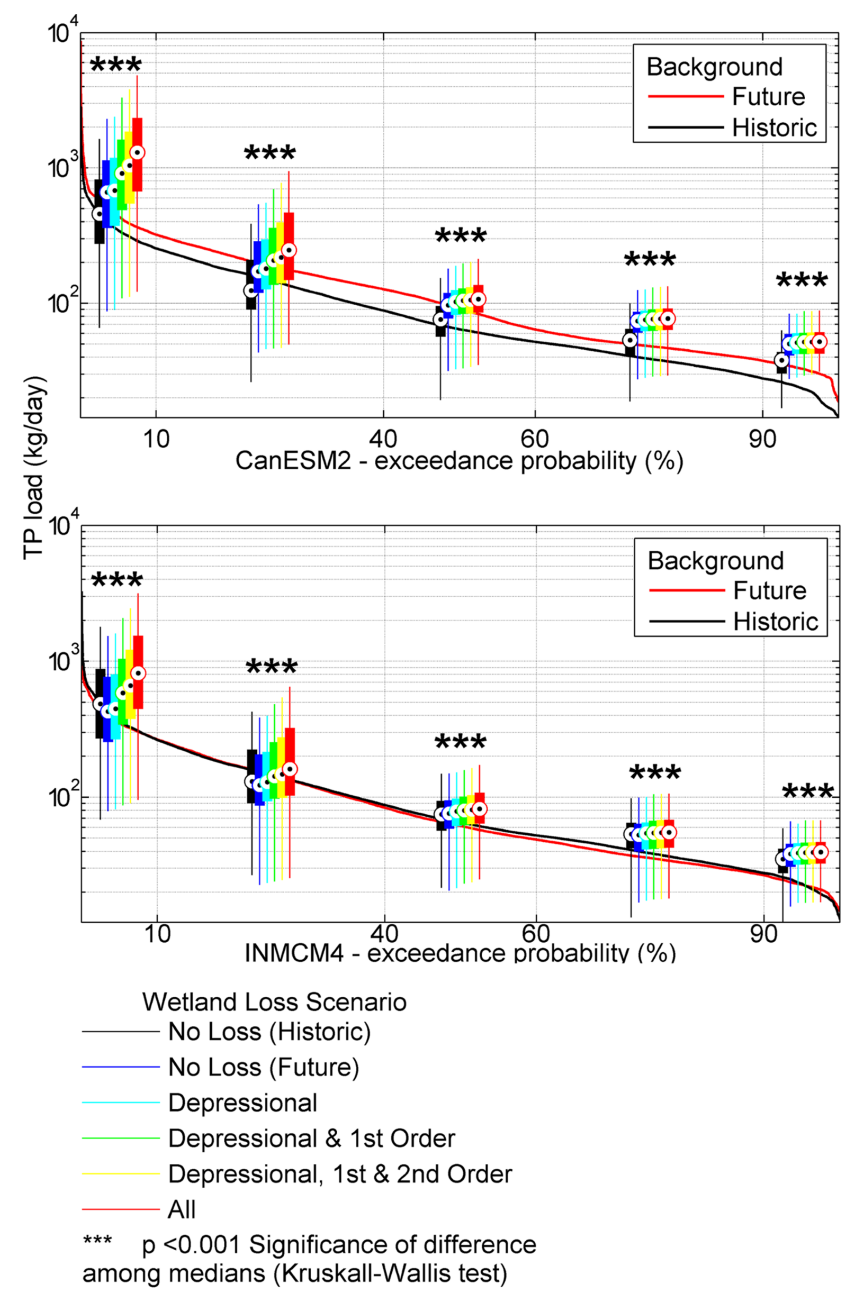

Figure 5. Annual TP load duration curves under two general circulation models for the historic period (1954-2005) and for Representative Concentration Pathway (RCP) 8.5 future period (2030-2059). Box centers show medians, and whiskers show the 25th and 75th percentiles of daily simulated loads in five flow classes. As there is inherent uncertainty in the modeling framework, we draw the reader's attention to the relative rather than absolute differences between scenarios and time periods.

watersheds were more effective during high flows in removing suspended solids and TP from runoff. However, Hoffmann et al. (2009) noted that, in many cases, P retention in riparian buffers decreases with increased hydraulic loading. Ultimately, the effects of riparian buffers on in-stream $P$ will vary with the form of $\mathrm{P}$, how $\mathrm{P}$ is retained in the buffer (whether by sorption to sediments, plant uptake, or another means), and riparian zone hydrology (Hoffmann et al., 2009).

Climate-induced changes to TP inflows are more important to Upper Klamath Lake's ecological status than changes in TN because A. flos-aquae, the dominant cyanobacteria in the lake, is P-limited (Boyd et al., 2002; Walker et al., 2012). The effects due to changes in climate, wetland area or land use, or some combination of these, on lake processes resulting from TP loading from the watershed, will be complicated by climate change acting directly on the lake itself.

First, the changes in flow volume concurrent with increased loading are likely to alter residence times of pollutants in lakes and streams (Murdoch et al., 2000). Residence times will also be affected by water use, since lake levels are managed for Endangered Species Act mandates and the needs of downstream users (VanderKooi et al., 2011). As Jeppesen et al. (2009) have noted, changes in residence time could alter lake TP concentrations by changes to lake inflow concentration, hydraulic retention time, or both.

Second, future warmer air temperatures could extend the growing season, also leading to warmer water and thus decreased oxygen saturation. Anoxic conditions free sedimentbound, soluble P into the water column (Solheim et al., 2010), so this could increase internal P loading in Upper Klamath Lake. Upper Klamath Lake bed records suggest that accelerated erosion in the last century is partly responsible for the lake's hypereutrophication (Boyd et al., 2002). If climate change results in large increases in erosion disproportionate to stream flow, as could occur with more rain and less snow (e.g., as in our "warmer-wetter" simulation described above), this could contribute to more internal $\mathrm{P}$ loading in the lake.

Third, higher temperatures might alter lake stratification and turnover (Murdoch et al., 2000; Solheim et al., 2010). Finally, there appears to be a lag time of unknown length in Upper Klamath Lake's response to nutrient load changes, in part because of internal loading of $\mathrm{P}$ from lake sediments (Walker et al., 2012), so it is uncertain how and when the lake or the Klamath River downstream would respond to changes in lake inflow.

Water quality changes in the Sprague River and other lake tributaries are also important for resident fish species such as Oncorhynchus mykiss (Interior redband trout) (Boyd et al., 2002), and, if dam removal and restoration efforts in the Lower Klamath River are successful, for anadromous salmonids once present in the Upper Klamath Basin. Water quality impacts in tributaries are likely to vary between headwaters and higher-order streams and will depend on changes in stream flow and residence time and whether nutrients are soluble or particulate (Withers and Jarvie, 2008). Large sections of the Sprague River have already been listed by the US Environmental Protection Agency as water quality impaired due to low dissolved oxygen in summer and high $\mathrm{pH}$ - both of which are associated with nutrient loads, in-stream algal growth, and a third impairment, high stream temperature (Boyd et al., 2002). Regional stream temperatures are likely to increase with warmer future air temperatures (Flint and Flint, 2011), further decreasing oxygen saturation and potentially promoting algal growth and exacerbating existing water quality impairments.

As in other climate impact studies, this study incorporates multiple sources of uncertainty. These include hydrologic model uncertainty, measurement uncertainty in calibration 
Table 5. Calibration $(C)$ and validation $(V)$ statistics for Sprague River tributaries and main stem. The calibration period is 2001-2006, and the validation period is 2007-2010, except for flow at the South Fork of the Sprague River, where calibration is for even years from October 1992 to September 2003 and validation is for odd years for the same period. All statistics are monthly except sediment and nutrient statistics for the South Fork of the Sprague River, which are daily. Numbers following tributary name correspond to numbered flow (first) and water quality sampling location (second) shown in Fig. 1.

\begin{tabular}{|c|c|c|c|c|c|c|c|c|}
\hline \multirow[t]{2}{*}{ Statistic } & \multicolumn{2}{|c|}{ Flow } & \multicolumn{2}{|c|}{ Sed } & \multicolumn{2}{|c|}{$\mathrm{TP}$} & \multicolumn{2}{|c|}{$\mathrm{TN}$} \\
\hline & $C$ & $V$ & $C$ & $V$ & $C$ & $V$ & $C$ & $V$ \\
\hline \multicolumn{9}{|c|}{ North Fork of the Sprague River $(6,5)$} \\
\hline$P_{\mathrm{BIAS}}(\%)$ & -8 & -31 & 6 & -18 & 1 & -16 & 0 & 0 \\
\hline$R^{2}$ & 0.85 & 0.89 & 0.88 & 0.82 & 0.87 & 0.71 & 0.91 & 0.9 \\
\hline NS & 0.71 & 0.67 & 0.69 & 0.63 & 0.73 & 0.42 & 0.74 & 0.63 \\
\hline \multicolumn{9}{|c|}{ South Fork of the Sprague River $(8,7)$} \\
\hline$P_{\mathrm{BIAS}}(\%)$ & 21 & 17 & 11 & 12 & 22 & 28 & 94 & 97 \\
\hline & 0.9 & 0.83 & 0.79 & 0.78 & 0.54 & 0.62 & 0.64 & 0.69 \\
\hline NS & 0.78 & 0.68 & 0.62 & 0.58 & 0.27 & 0.34 & -0.31 & -0.41 \\
\hline \multicolumn{9}{|c|}{ Sycan River $(3,4)$} \\
\hline$P_{\text {BIAS }}(\%)$ & 20 & 17 & 10 & 9 & 32 & 36 & 67 & 95 \\
\hline$R^{2}$ & 0.94 & 0.88 & 0.95 & 0.89 & 0.88 & 0.85 & 0.72 & 0.85 \\
\hline NS & 0.82 & 0.66 & 0.89 & 0.78 & 0.74 & 0.6 & 0.42 & -0.29 \\
\hline \multicolumn{9}{|c|}{ Sprague River main stem $(1,2)$} \\
\hline$P_{\mathrm{BIAS}}(\%)$ & 3 & -6 & -20 & 10 & 10 & -26 & 37 & 19 \\
\hline$R^{2}$ & 0.93 & 0.85 & 0.94 & 0.81 & 0.85 & 0.63 & 0.81 & 0.7 \\
\hline NS & 0.84 & 0.7 & 0.86 & 0.62 & 0.7 & 0.28 & 0.56 & 0.45 \\
\hline
\end{tabular}

data, and uncertainty in climate projections. The latter incorporates uncertainty in global forcings, such as future greenhouse gas levels, the physical response of the climate system in the GCM formulation, and internal model variability of the GCMs (Rupp et al., 2013). While we acknowledge the value of a detailed uncertainty analysis in interpreting results presented here, such an analysis is beyond the scope of the current study. In our framework, riparian areas uptake a fraction of sediment and nutrients from flow contributed from hillslopes to streams but do not interact with the basin hydrology. However, the effect of riparian zones on stream water quality under future climate will likely be influenced by complex hydrologic interactions between the hillslope, riparian areas, and streams. This should be taken into consideration when interpreting the study results.

We cannot yet say where or how wetlands may change under 21 st-century climate. This question should be addressed at a later date through models of future wetland occurrence and persistence. However, we can evaluate system vulnerability by assessing hypothetical land use and climate change scenarios, as we have shown here.

\section{Conclusions}

Although our study area was located in the western US, the general methodological framework should be transferable to other watersheds. Because land cover change under future conditions is uncertain and comprehensive modeling of these changes may be beyond available resources, we suggest that land cover scenarios be considered a first-order analysis of future system sensitivity. The main components of this framework can be extracted from Fig. 2. In order, these steps are (1) the development of an appropriate hydrologic model; (2) the selection of climate scenarios from downscaled GCMs, synthetic data, or other sources; and (3) the application of hypothetical scenarios of land cover change, taking into account plausible future climatic and land use conditions.

To our knowledge, this is the first study to investigate potential impacts of climate change on nutrient loads in a $\mathrm{Pa}$ cific Northwest snowmelt-dominated river and the first to characterize potential combined effects of climate change and wetland loss on basin-scale stream water quality. Our findings suggest that in the snowmelt-dominated Sprague River of southern Oregon, USA, (1) mid-21st centurynutrient 
and sediment loads could increase significantly during the high-flow season under warmer, wetter climate projections or could change little in a warmer and somewhat drier future. They also suggest (2) that, although water quality conditions under future climate and no wetland loss may be similar to the past, the combined impact of climate change and wetland losses on nutrient loads could be large; (3) that increases in stream TP concentration with wetland loss under future climates would be greatest at high-magnitude, lowprobability flows; and (4) that the loss of riparian wetlands in both headwaters and lowlands could increase outlet TP loads to a similar degree, but this could be due to distinctly different mechanisms in different parts of the watershed. This study also implies that the conservation of existing wetlands is a critical management strategy to minimize in-stream nutrient load increases under diverse future climate scenarios. Future changes in Pacific Northwest hydrology have been the focus of a number of studies; our findings suggest that associated changes in water quality may be significant and merit more research.

\section{The Supplement related to this article is available online at doi:10.5194/hess-11-4509-2014-supplement.}

Acknowledgements. We would like to thank Genevieve Ali and an anonymous reviewer for their constructive feedback on the manuscript. This work was generously supported by the US Department of Agriculture Natural Resources Conservation Service Conservation Effects Assessment Project (CEAP-Wetlands). We also wish to thank the Klamath Tribes Research Station and other Klamath Basin organizations for generously making available the data used in model calibration and validation, and Joseph Essamuah-Quansah for valuable consultations in early stages of this work.

Edited by: J. Liu

\section{References}

Abatzoglou, J. T.: Development of gridded surface meteorological data for ecological applications and modelling, Int. J. Climatol., 33, 121-131, doi:10.1002/joc.3413, 2013.

Abatzoglou, J. T. and Brown, T. J.: A comparison of statistical downscaling methods suited for wildfire applications, Int. J. Climatol., 32, 772-780, doi:10.1002/joc.2312, 2012.

Abbaspour, K. C., Faramarzi, M., Ghasemi, S. S., and Yang, H.: Assessing the impact of climate change on water resources in Iran, Water Resour. Res., 45, W10434, doi:10.1029/2008WR007615, 2010.

Ahmadi, M., Records, R., and Arabi, M.: Impact of climate change on diffuse pollutant fluxes at the watershed scale, Hydrol. Process., 28, 1962-1972, doi:10.1002/hyp.9723, 2014.
Almendinger, J. E., Murphy, M. S., and Ulrich, J. S.: Use of the Soil and Water Assessment Tool to scale sediment delivery from field to watershed in an agricultural landscape with topographic depressions, J. Environ. Qual., 43, 9-17, doi:10.2134/jeq2011.0340, 2012.

American Society of Agricultural and Biological Engineers: ASAE D384.2 MAR2005 Manure production and characteristics, ASABE, St. Joseph, Minnesota, USA, 2006.

Arnold, J. G., Srinivasan, R., Muttiah, R. S., and Williams, J. R.: Large area hydrologic modeling and assessment, part I: model development, J. Am. Water Resour. Assoc., 34, 73-89, 1998.

Beechie, T., Imaki, H., Greene, J., Wade, A., Wu, H., Pess, G., Roni, P., Kimball, J., Stanford, J., Kiffney, P., and Mantua, N.: Restoring salmon habitat for a changing climate, River Res. Appl., 29, 939-960, doi:10.1002/rra.2590, 2013.

Bosch, N. S.: The influence of impoundments on riverine nutrient transport: an evaluation using the Soil and Water Assessment Tool, J. Hydrol., 355, 131-147, doi:10.1016/j.jhydrol.2008.03.012, 2008.

Bouraoui, F., Galbiati, L., and Bidoglio, G.: Climate change impacts on nutrient loads in the Yorkshire Ouse catchment (UK), Hydrol. Earth Syst. Sci., 6, 197-209, doi:10.5194/hess-6-197-2002, 2002.

Boyd, M., Kirk, S., Wiltsey, M., and Kasper, B.: Upper Klamath Lake Drainage Total Maximum Daily Load (TMDL) and Water Quality Management Plan (WQMP), State of Oregon Department of Environmental Quality, Portland, Oregon, USA, 2002.

Bracmort, K. S., Arabi, M., Frankenberger, J. R., Engel, B. A., and Arnold, J. G.: Modeling long-term water quality impact of structural BMPs, Trans. ASABE, 49, 367-374, 2006.

Brown, L. C. and Barnwell, T. O.: The enhanced water quality models QUAL2E and QUAL2E-UNCAS documentation and user manual, Technical Report EPA Document EPA/600/3-87/007, Athens, Georgia, USA, 1987.

Burkett, V. and Kusler, J.: Climate change: potential impacts and interactions in wetlands of the United States, J. Am. Water Resour. Assoc., 36, 313-320, 2000.

Cahoon, J.: Soil survey report of Klamath County, Oregon, southern part, US Soil Conservation Service, Oregon State University, and Agricultural Experiment Station, Washington, D.C., USA, 1985.

Candela, L., von Igel, W., Javier Elorza, F., and Aronica, G.: Impact assessment of combined climate and management scenarios on groundwater resources and associated wetland (Majorca, Spain), J. Hydrol., 376, 510-527, doi:10.1016/j.jhydrol.2009.07.057, 2009.

CH2MHILL: Approaches to water quality treatment by wetlands in the Upper Klamath Basin, Prepared for PacifiCorp Energy, Portland, Oregon, USA, 2012.

Chaplot, V.: Water and soil resources response to rising levels of atmospheric $\mathrm{CO}_{2}$ concentration and to changes in precipitation and air temperature, J. Hydrol., 337, 159-171, doi:10.1016/j.jhydrol.2007.01.026, 2007.

Cho, J., Vellidis, G., Bosch, D. D., Lowrance, R., and Strickland, T.: Water quality effects of simulated conservation practice scenarios in the Little River Experimental Watershed, J. Soil Water Conserv., 65, 463-473, doi:10.2489/jswc.65.6.463, 2010a. 
Cho, J., Lowrance, R. R., Bosch, D. D., Strickland, T. C., Her, Y., and Vellidis, G.: Effect of watershed subdivision and filter width on SWAT simulation of a coastal plain watershed, J. Am. Water Resour. Assoc., 46, 586-602, doi:10.1111/j.17521688.2010.00436.x, 2010b.

Ciotti, D. C.: Water quality of runoff from flood irrigated pasture in the Klamath Basin, Oregon, M.S. thesis, Oregon State University, Corvallis, Oregon, USA, 2005.

Ciotti, D., Griffith, S. M., Kann, J., and Baham, J.: Nutrient and sediment transport on flood-irrigated pasture in the Klamath Basin, Oregon, Rangel. Ecol. Manage., 63, 308-316, doi:10.2111/08127.1, 2010.

Diffenbaugh, N. S., Scherer, M., Ashfaq, M., and Ortega, V.: Response of snow-dependent hydrologic extremes to continued global warming, Nat. Clim. Change, 3, 379-384, doi:10.1038/NCLIMATE1732, 2013.

Durre, I., Menne, M. J., Gleason, B. E., Houston, T. G., and Vose, R. S.: Comprehensive automated quality assurance of daily surface observations, J. Appl. Meteorol. Climatol., 49, 1615-1633, doi:10.1175/2010JAMC2375.1, 2010.

Eldridge, S. L. C., Wood, T. W., and Echols, K. R.: Spatial and temporal dynamics of cyanotoxins and their relation to other water quality variables in Upper Klamath Lake, Oregon, 2007-09, Scientific Investigations Report 2012-5069, US Geological Survey, Reston, Virginia, USA, 2012.

Engel, B., Storm, D., White, M., Arnold, J., and Arabi, M.: A hydrologic/water quality model application protocol, J. Am. Water Resour. Assoc., 43, 1223-1236, doi:10.1111/j.17521688.2007.00105.x, 2007.

Ficklin, D. L., Luo, Y., Luedeling, E., Gatzke, S. E., and Zhang, M.: Sensitivity of agricultural runoff loads to rising levels of $\mathrm{CO}_{2}$ and climate change in the San Joaquin Valley watershed of California, Environ. Pollut., 158, 223-234, doi:10.1016/j.envpol.2009.07.016, 2010.

Ficklin, D. L., Stewart, I. T., and Maurer, E. P.: Effects of climate change on stream temperature, dissolved oxygen, and sediment concentration in the Sierra Nevada in California, Water Resour. Res., 49, 2765-2782, doi:10.1002/wrcr.20248, 2013.

Flint, L. E. and Flint, A. L.: Estimation of stream temperature in support of fish production modeling under future climates in the Klamath River Basin, Scientific Investigations Report 20115171, US Geological Survey, Reston, Virginia, USA, 2011.

Gannett, M. W., Lite Jr., K. E., La Marche, J. L., Fisher, B. J., and Polette, D. J.: Ground-water hydrology of the Upper Klamath Basin, Oregon and California, Scientific Investigations Report 2007-5050, Reston, Virginia, USA, 2007.

Gassman, P. W., Reyes, M. R., Green, C. H., and Arnold, J. G.: The Soil and Water Assessment Tool: historical development, applications, and future research directions, Trans. ASABE, 50, 1211-1250, 2007.

Gearheart, R. A., Anderson, J. K., Forbes, M. G., Osburn, M., and Oros, D.: Watershed strategies for improving water quality in Upper Klamath Lake, Oregon, Volumes I, Humboldt State University, Arcata, California, USA, 1995.

Graham Matthews and Associates: Sprague River watershed: streamflow, sediment transport and a preliminary sediment budget, WY2004-2006, Weaverville, California, USA, 2007.
Graham, S. A., Craft, C. B., McCormick, P. V., and Aldous, A.: Forms and accumulation of soil $\mathrm{P}$ in natural and recently restored peatlands - Upper Klamath Lake, Oregon, USA, Wetlands, 25, 594-606, 2005.

Gu, A. Z., Liu, L., Neethling, J. B., Stensel, H. D., and Murthy, S.: Treatability and fate of various phosphorus fractions in different wastewater treatment processes, Water Sci. Technol., 29, 804-810, 2011.

Hamlet, A. F., Mote, P. W., Clark, M. P., and Lettenmaier, D. P.: Twentieth-century trends in runoff, evapotranspiration, and soil moisture in the Western United States, J. Climate, 20, 1468-1486, doi:10.1175/JCLI4051.1, 2007.

Helsel, D. R. and Hirsch, R. M.: Chapter A3: Statistical Methods in Water Resources, in: Techniques of Water-Resources Investigations of the United States Geologic Survey: Book 4, Hydrologic Analysis and Interpretation, vol. 36, US Geological Survey, Reston, Virginia, USA, 1-510, 2002.

Hoffmann, C. C., Kjaergaard, C., Uusi-Kämppä, J., Hansen, H. C. B., and Kronvang, B.: Phosphorus retention in riparian buffers: review of their efficiency, J. Environ. Qual., 38, 1942-1955, doi:10.2134/jeq2008.0087, 2009.

Homer, C., Huang, C., Yang, L., Wylie, B., and Coan, M.: Development of a 2001 national land-cover database for the United States, Photogramm. Eng. Remote Sens., 70, 829-840, 2004.

Homer, C., Dewitz, J., Fry, J., Coan, M., Hossain, N., Larson, C., Herold, N., McKerrow, A., VanDriel, J. N., and Wickham, J.: Completion of the 2001 National Land Cover Database for the conterminous United States, Photogramm. Eng. Remote Sens., 73, 337-341, 2007.

Isaak, D. J., Luce, C. H., Rieman, B. E., Nagel, D. E., Peterson, E. E., Horan, D. L., Parkes, S., and Chandler, G. L.: Effects of climate change and wildfire on stream temperatures and salmonid thermal habitat in a mountain river network, Ecol. Appl., 20, 1350-1371, 2010.

Jefferson, A. J.: Seasonal versus transient snow and the elevation dependence of climate sensitivity in maritime mountainous regions, Geophys. Res. Lett., 38, L16402, doi:10.1029/2011GL048346, 2011.

Jeppesen, E., Kronvang, B., Meerhoff, M., Søndergaard, M., Hansen, K. M., Andersen, H. E., Lauridsen, T. L., Liboriussen, L., Beklioglu, M., Ozen, A., and Olesen, J. E.: Climate change effects on runoff, catchment phosphorus loading and lake ecological state, and potential adaptations, J. Environ. Qual., 38, 1930-1941, doi:10.2134/jeq2008.0113, 2009.

Jha, M. K., Gassman, P. W., and Arnold, J. G.: Water quality modeling for the Raccoon River watershed using SWAT, Trans. ASABE, 50, 479-494, 2007.

Jha, M., Pan, Z., Takle, E. S., and Gu, R.: Impacts of climate change on streamflow in the Upper Mississippi River Basin: a regional climate model perspective, J. Geophys. Res., 109, D09105, doi:10.1029/2003JD003686, 2004.

Johnston, C. A., Detenbeck, N. E., and Niemi, G. J.: The cumulative effect of wetlands on stream water quality and approach quantity: A landscape approach, Biogeochemistry, 10, 105-141, 1990.

Klamath Tribes: Quality Assurance Project Plan (QAPP) project: baseline water quality monitoring project, Chiloquin, Oregon, USA, 2008. 
Krysanova, V., Hattermann, F., and Wechsung, F.: Development of the ecohydrological model SWIM for regional impact studies and vulnerability assessment, Hydrol. Process., 19, 763-783, doi:10.1002/hyp.5619, 2005.

Kundzewicz, Z. W., Mata, L. J., Arnell, N. W., Doll, P., Jimenez, B., Miller, K., Oki, T., Sen, Z., and Shiklomanov, I.: The implications of projected climate change for freshwater resources and their management, Hydrol. Sci., 53, 3-10, 2009.

Lam, Q. D., Schmalz, B., and Fohrer, N.: The impact of agricultural Best Management Practices on water quality in a North German lowland catchment, Environ. Monit. Assess., 183, 351-379, doi:10.1007/s10661-011-1926-9, 2011.

Li, H., Sheffield, J., and Wood, E. F.: Bias correction of monthly precipitation and temperature fields from Intergovernmental Panel on Climate Change AR4 models using equidistant quantile matching, J. Geophys. Res.-Atmos., 115, D10101, doi:10.1029/2009JD012882, 2010.

Li, Y., Chen, B. M., Wang, Z. G., and Peng, S. L.: Effects of temperature change on water discharge, and sediment and nutrient loading in the lower Pearl River basin based on SWAT modelling, Hydrolog. Sci. J., 56, 68-83, doi:10.1080/02626667.2010.538396, 2011.

Liu, J., You, L., Amini, M., Obersteiner, M., Herrero, M., Zehnder, A. J. B., and Yang, H.: A high-resolution assessment on global nitrogen flows in cropland, P. Natl. Acad. Sci. USA, 107, 8035-8040, doi:10.1073/pnas.0913658107, 2010.

Liu, Y., Yang, W., and Wang, X.: GIS-based integration of SWAT and REMM for estimating water quality benefits of riparian buffers in agricultural watersheds, Trans. ASABE, 50, 1549-1563, 2007.

Liu, Y., Yang, W., and Wang, X.: Development of a SWAT extension module to simulate riparian wetland hydrologic processes at a watershed scale, Hydrol. Process., 22, 2901-2915, doi:10.1002/hyp.6874, 2008.

Lowrance, R., Altier, L. S., Newbold, J. D., Schnabel, R. R., Groffman, P. M., Denver, J. M., Correll, D. L., Gilliam, J. W., Robinson, J. L., Todd, A. H., Brinsfield, R. B., Staver, K. W., Lucas, W., and Todd, A. H.: Water quality functions of riparian forest buffers in Chesapeake Bay watersheds, Environ. Manage., 21, 687-712, 1997.

Ma, K., You, L., Liu, J., and Zhang, M.: A hybrid wetland map for China: a synergistic approach using census and spatially explicit datasets, PLOS ONE, 7, e47814, doi:10.1371/journal.pone.0047814, 2012.

Mayer, T. D. and Naman, S. W.: Streamflow response to climate as influenced by geology and elevation, J. Am. Water Resour. Assoc., 47, 724-738, doi:10.1111/j.1752-1688.2011.00537.x, 2011

Melles, S. J., Benoy, G., Booty, B., Leon, L., Vanrobaeys, J., and Wong, I: Scenarios to Investigate the Effect of Wetland Position in a Watershed on nutrient loadings, in: Proceedings of International Environmental Modelling and Software Society, 2010 International Congress on Environmental Modelling and Software Modelling for Environment's Sake, Fifth Biennial Meeting, Ottawa, Canada, 2010.

Meyer, J. L., Sale, M. J., Mulholland, P. J., and Poff, N. L.: Impacts of climate change on aquatic ecosystem functioning and health, J. Am. Water Resour. Assoc., 35, 1373-1386, 1999.
Mitsch, W. J. and Gosselink, J. G.: The value of wetlands: importance of scale and landscape setting, Ecol. Econ., 35, 25-33, 2000a.

Mitsch, W. J. and Gosselink, J. G.: Wetlands, 3rd Edn., John Wiley and Sons, Inc., New York, USA, $2000 \mathrm{~b}$.

Moriasi, D. N., Arnold, J. G., Van Liew, M. W., Bingner, R. L., Harmel, R. D., and Veith, T. L.: Model evaluation guidelines for systematic quantification of accuracy in watershed simulations, Trans. ASABE, 50, 885-900, 2007.

Moriasi, D. N., Steiner, J. L., and Arnold, J. G.: Sediment measurement and transport modeling: impact of riparian and filter strip buffers, J. Environ. Qual., 40, 807-814, doi:10.2134/jeq2010.0066, 2011.

Morris, M. D.: Factorial sampling plans for preliminary computational experiments, Technometrics, 33, 161-174, 1991.

Mote, P. W.: Trends in snow water equivalent in the Pacific Northwest and their climatic causes, Geophys. Res. Lett., 30, 3-1-3-4, doi:10.1029/2003GL017258, 2003.

Mote, P. W. and Salathé Jr., E. P.: Future climate in the Pacific Northwest, Climatic Change, 102, 29-50, doi:10.1007/s10584010-9848-z, 2010.

Mulholland, P. J. and Sale, M. J.: Impacts of climate change on water resources: findings of the IPCC Regional Assessment of Vulnerability for North America, J. Contemp. Water Res. Educ., 112, 10-15, 2011.

Murdoch, P. S., Baron, J. S., and Miller, T. L.: Potential effects of climate change on surface-water quality in North America, J. Am. Water Resour. Assoc., 36, 347-366, 2000.

Neitsch, S. L., Arnold, J. G., Kiniry, J. R., and Williams, J. R.: Soil and Water Assessment Tool Theoretical Documentation Version 2005, Texas A\& M University, College Station, Texas, USA, 2005.

Neitsch, S. L., Arnold, J. G., Kiniry, J. R., and Williams, J. R.: Soil and Water Assessment Tool Theoretical Documentation Version 2009, Texas Water Resources Institute Technical Report No. 406, Texas A \& M University, College Station, Texas, USA, 2009.

Novotny, V.: Water Quality: Diffuse Pollution and Watershed Management, 2nd Edn., J. Wiley, Hoboken, New Jersey, USA, 2003.

Oregon Climate Change Research Institute: Oregon Climate Assessment Report, edited by: Dello, K. D. and Mote, P. W., College of Oceanic and Atmospheric Sciences, Oregon State University, Corvallis, Oregon, USA, 2010.

Oregon Natural Heritage Information Center and the Wetlands Conservancy: Oregon Wetland Geodatabase vector digital data, available at http://spatialdata.oregonexplorer.info/ (last access: 28 July 2012), 2009.

Oregon Water Resources Department: Oregon Water Rights Places of Use (POUs), by administrative basin vector digital data, available at: http://www.oregon.gov/owrd/pages/wr/index.aspx (last access: 22 July 2011), 2008.

Park, J. Y., Park, M. J., Ahn, S. R., Park, G. A., Yi, J. E., Kim, G. S., Srinivasan, R., and Kim, S. J.: Assessment of future climate change impacts on water quantity and quality for a mountainous dam watershed using SWAT, Trans. ASABE, 54, 1725-1737, 2011. 
Perry, L. G., Andersen, D. C., Reynolds, L. V., Nelson, S. M., and Shafroth, P. B.: Vulnerability of riparian ecosystems to elevated $\mathrm{CO}_{2}$ and climate change in arid and semiarid western North America, Global Change Biol., 18, 821-842, doi:10.1111/j.1365-2486.2011.02588.x, 2012.

Pierce, D. W., Westerling, A. L., and Oyler, J.: Future humidity trends over the western United States in the CMIP5 global climate models and variable infiltration capacity hydrological modeling system, Hydrol. Earth Syst. Sci., 17, 1833-1850, doi:10.5194/hess-17-1833-2013, 2013.

Pionke, H. B., Gburek, W. J., and Sharpley, A. N.: Critical source area controls on water quality in an agricultural watershed located in the Chesapeake Basin, Ecol. Eng., 14, 325-335, 2000.

PRISM Climate Group at Oregon State University: United States Average Monthly or Annual Maximum Temperature, Minimum Temperature, and Precipitation, 1981-2010, available at: http:// prism.nacse.org/normals/ (last access: 2 February 2013), 2012.

Rabe, A. and Calonje, C.: Lower Sprague-Lower Williamson watershed assessment, Prepared for Klamath Watershed Partnership, Klamath Falls, Oregon, USA, 2009.

Risley, J., Hay, L. E., and Markstrom, S.: Watershed scale response to climate change - Sprague River Basin, Oregon, US Geological Survey Fact Sheet 2011-3120, Denver, US Geological Survey, Colorado, USA, 2012.

Runkel, R. L., Crawford, C. G. and Cohn, T. A.: Load Estimator (LOADEST): a FORTRAN program for estimating constituent loads in streams and rivers, Techniques and Methods Book 4, Chapter A5, US Geological Survey, Reston, Virginia, USA, 1-56, 2004.

Rupp, D. E., Abatzoglou, J. T., Hegewisch, K. C., and Mote, P. W.: Evaluation of CMIP5 $20^{\text {th }}$ century climate simulations for the Pacific Northwest USA, J. Geophys. Res.-Atmos., 118, 1-23, doi:10.1002/jgrd.50843, 2013.

Sahu, M. and Gu, R. R.: Modeling the effects of riparian buffer zone and contour strips on stream water quality, Ecol. Eng., 35, 1167-1177, doi:10.1016/j.ecoleng.2009.03.015, 2009.

SalathéJr., E. P., Mote, W., and Wiley, M. W.: Review of scenario selection and downscaling methods for the assessment of climate change impacts on hydrology in the United States Pacific Northwest, Int. J. Climatol., 1621, 1611-1621, doi:10.1002/joc.1540, 2007.

Santhi, C., Arnold, J. G., Williams, J. R., Dugas, W. A., Srinivasan, R., and Hauck, L. M.: Validation of the SWAT model on a large river basin with point and nonpoint sources, J. Am. Water Resour. Assoc., 37, 1169-1188, 2001.

Serreze, M. C., Clark, M. P., Armstrong, R. L., McGinnis, D. A., and Pulwarty, R. S.: Characteristics of the western United States snowpack from snowpack telemetry (SNOTEL) data, Water Resour., 35, 2145-2160, 1999.

Sharpley, A. N. and Williams, J. R. (Eds.): EPIC - Erosion Productivity Impact Calculator, 1. Model documentation, US Department of Agriculture, Agricultural Research Service, Technical Bulletin 1768, Durant, Oklahoma, USA, 1990.

Shrestha, R. R., Dibike, Y. B., and Prowse, T. D.: Modeling climate change impacts on hydrology and nutrient loading in the Upper Assiniboine Catchment, J. Am. Water Resour. Assoc., 48, 74-89, doi:10.1111/j.1752-1688.2011.00592.x, 2012.
Solheim, A. L., Austnes, K., Eriksen, T. E., Seifert, I., and Holen, S.: Climate change impacts on water quality and biodiversity: background report for EEAA European Environment State and Outlook Report 2010, ETC Water Technical Report 1/2010, EEAA, Prague, Czech Republic, 2010.

Sproles, E. A., Nolin, A. W., Rittger, K., and Painter, T. H.: Climate change impacts on maritime mountain snowpack in the Oregon Cascades, Hydrol. Earth Syst. Sci., 17, 2581-2597, doi:10.5194/hess-17-2581-2013, 2013.

Stewart, I. T., Cayan, D. R., and Dettinger, M. D.: Changes toward earlier streamflow timing across western North America, J. Climate, 18, 1136-1155, 2005.

Strahler, A. N.: Dynamic basis of geomorphology, Geol. Soc. Am. Bull., 63, 923-938, 1952.

Taylor, K. E., Stouffer, R. J., and Meehl, G. A.: An overview of CMIP5 and the experiment design, B. Am. Meteorol. Soc., 93, 485-498, doi:10.1175/BAMS-D-11-00094.1, 2012.

Tillman, P. and Siemann, D.: Climate change effects and adaptation approaches in freshwater aquatic and riparian ecosystems in the North Pacific landscape conservation cooperative region, National Wildlife Federation, Seattle, Washington, USA, 2011.

Tolson, B. A. and Shoemaker, C. A.: Dynamically dimensioned search algorithm for computationally efficient watershed model calibration, Water Resour. Res., 43, W01413, doi:10.1029/2005WR004723, 2007.

Tomer, M. D., Gosskey, M. G., Burkart, M. R., James, D. E.. and Helmers, M. J.: Methods to prioritize placement of riparian buffers for improved water quality, Agroforest Syst., 75, 17-25, 2009.

US Department of Agriculture Agricultural Research Service: ArcSWAT 2009.93.7b, available at: http://swat.tamu.edu/, last access: 1 December 2011.

US Department of Agriculture Natural Resources Conservation Service: Sprague River CEAP Study Report, Portland, Oregon, USA, 2009.

US Department of Agriculture Natural Resources Conservation Service: the National Easement Dataset vector digital data, US Department of Agriculture, Natural Resources Conservation Service, National Cartography and Geospatial Center, Fort Worth, Texas, USA, 2011.

US Environmental Protection Agency: An approach for using Load Duration Curves in the development of TMDLs, Wetlands Branch, Office of Wetlands and Watersheds, US Environmental Protection Agency, Washington, D.C., USA, 2007.

US Fish and Wildlife Service: Classification of wetlands and deepwater habitats of the United States vector digital data, US Fish and Wildlife Service Division of Habitat and Resource Conservation, Washington, D.C., USA, available at: http://www.fws. gov/wetlands/data/Data-Download.html, last access: 19 February 2011.

US Geological Survey: 1-Arc Second National Elevation Dataset SDE raster digital data, available at: http://seamless.usgs.gov (last access: 20 May 2010), 2009.

US Geological Survey: NHD Flowline vector digital data, NHD High Resolution. pre-staged by sub-basin, available at: ftp://nhdftp.usgs.gov/DataSets/Staged/SubRegions/FileGDB/ HighResolution/ (last access: 28 March 2012), 2010a. 
US Geological Survey: NHD Waterbody vector digital data, available at: ftp://nhdftp.usgs.gov/DataSets/Staged/SubRegions/ FileGDB/HighResolution/ (last access: 8 August 2011), 2010b.

US Geological Survey: USGS 11501000 Sprague River near Chiloquin, OR, peak streamflow Oregon, available at: http://nwis.waterdata.usgs.gov/or/nwis/peak?site_no= 11501000\&agency_cd=USGS\&format=brief_list, last access: 10 October 2012.

VanderKooi, S., Thorsteinson, L., and Clark, M.: Chapter 2: Environmental and historical setting, in: Proceedings of the Klamath Basin Science Conference, 1-5 February 2010, Medford, Oregon, 31-36, 2011.

Van Liew, M. W., Feng, S., and Pathak, T. B.: Climate change impacts on streamflow, water quality, and best management practices for the Shell and Logan creek watersheds in Nebraska, Int. J. Agric. Biol. Eng., 5, 13-34, 2012.

Verhoeven, J. T. A., Arheimer, B., Yin, C., and Hefting, M. M.: Regional and global concerns over wetlands and water quality, Trends Ecol. Evol., 21, 96-103, doi:10.1016/j.tree.2005.11.015, 2006.

Waibel, M. S., Gannett, M. W., Chang, H., and Hulbe, C. L.: Spatial variability of the response to climate change in regional groundwater systems - Examples from simulations in the Deschutes Basin, Oregon, J. Hydrol., 486, 187-201, doi:10.1016/j.jhydrol.2013.01.019, 2013.

Walker, W., Walker, J., and Kann, J.: Evaluation of water and nutrient balances for the Upper Klamath Lake Basin in water years 1992-2010, Technical report to the Klamath Tribes Natural Resources Department, Chiloquin, Oregon, USA, 2012.

Wang, X., Yang, W., and Melesse, A. M.: Using hydrologic equivalent wetland concept within SWAT to estimate streamflow in watersheds with numerous wetlands, Trans. ASABE, 51, 55-72, 2008.
Wang, X., Shang, S., Qu, Z., Liu, T., Melesse, A. M., and Yang, W.: Simulated wetland conservation-restoration effects on water quantity and quality at watershed scale, J. Environ. Manage., 91, 1511-1525, doi:10.1016/j.jenvman.2010.02.023, 2010.

Whitehead, P. G., Wilby, R. L., Butterfield, D., and Wade, A. J.: Impacts of climate change on in-stream nitrogen in a lowland chalk stream: an appraisal of adaptation strategies, Sci. Total Environ., 365, 260-273, doi:10.1016/j.scitotenv.2006.02.040, 2006.

Winter, T. C: The vulnerability of wetlands to climate change: a hydrologic landscape perspective, J. Am. Water Resour. Assoc., 36, 305-311, doi:10.1111/j.1752-1688.2000.tb04269.x, 2000.

Withers, P. J. A. and Jarvie, H. P.: Delivery and cycling of phosphorus in rivers: a review, Sci. Total Environ., 400, 379-395, doi:10.1016/j.scitotenv.2008.08.002, 2008.

Wong, S. and Bienz, C.: Summary of Water Quality Sampling at Sycan Marsh, Oregon, 2010-2011, The Nature Conservancy, Klamath Falls, OR, USA, 2011.

Woznicki, S. A., Nejadhashemi, A. P., and Smith, C. M.: Assessing best management practice implementation strategies under climate change scenarios, Trans. ASABE, 54, 171-190, 2011.

$\mathrm{Wu}, \mathrm{K}$. and Johnston, C. A.: Hydrologic comparison between a forested and a wetland/lake dominated watershed using SWAT, Hydrol. Process., 22, 1431-1442, doi:10.1002/hyp.6695, 2008.

Zang, C. F., Liu, J., van der Velde, M., and Kraxner, F.: Assessment of spatial and temporal patterns of green and blue water flows under natural conditions in inland river basins in Northwest China, Hydrol. Earth Syst. Sci., 16, 2859-2870, doi:10.5194/hess-162859-2012, 2012. 